\title{
Ariel o la vida de Shelley
}

\author{
(Continuoción)
}

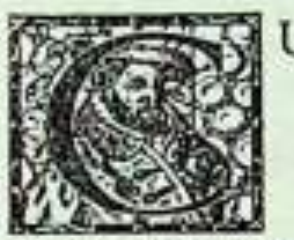

UANDO Mme. Boinville invitó a Shelley y Hogg a pasar algunos días en el campo, ambos aceptaron con placer. Encontraron alli a su hija Cornelia, mujer bonita, melancólica y culta, y su hermana Mrs. Newton. Shelley volvió a sentir las deliciosas impresiones de otras temporadas. Llamaba a Mme. de Boinville - Meimouné. porque, como la heroina de su poema lavorito:

Tenia el rostro de una joven

Aunque sus cabellos fueran grises.

La hermosa Cornelia le daba lecciones de italiano y Mme. de Boinville exponía con su voz pura la indulgente doctrina de los filósolos franceses: egoza y haz gozar, sin causar daño a nadie., he ahi toda la moral,: esta frase de Chamfort, tema favorito de Mme. de Boinville, habria debido indignar a Shelley. La pobre Harriet nunca habia dicho nada tan contrario a la virtud.

En Braknell las diversiones mismas le parecian agradables a Shelley. porque hasta los juegos estaban impregnados de filosofia. Cornelia acostumbraba leer y con frecuencia aprendia de memoria un soneto de Petrarca. Y todo el dia meditaba y se nutria del soneto. Al darle los buenos dias. Hogg y Shelley preguntábanle cuál era el soneto de la mañana. A veces el poema le parecia demasiado conmovedor para atreverse a recitarlo en voz alta: entonces habría el pequeño Petrarca de bolsillo que no le faltaba nunca y señalaba con el dedo el pasaje. Luego, paseando entre los dos jóvenes por las avenidas del parque, comentaba el texto amoroso con elocuencia y sencillez.

- Es bueno-decía-comenzar el día con una dosis de ternura que perfume los actos hasta el anochecer. .

Esos paseos, esas discusiones sobre los únicos temas que le parecian importantes y reales, esa casa a la vez opulenta y simple, cuya perfección le encantaba $\sin$ que le chocara su lujo, todo contribuia a hacer de Bracknell para Shelley un sitio de reposo y encantamiento. Harriet fué invitada: Mme. de Boinville la recibió condescendiente y bondadosa.

- Es una personita lindisima-declaró a Hogg.-Me parece algo frivola para nucstro delicioso estoico: pero ¿no tiene 18 años?

Por desdicha Harriet advirtió que no la trataban de igual a igual; vió que a Shelley gustaba más discutir con Cornelia sobre Petrarca que con su mujer los medios de aumentar los gastos de la casa; por reacción contra un ambiente que 
sentia confusamente hostil, bajo su aparente benevolencia, mostróse insesible y sarcástica. En los momentos más solemnes, cuando los otros hablaban de liberación y de virtud, su marido la veía cambiar sonrisas burlonas con Hogg y Peacock, nuevo amigo escéptico que habian descubierto hacia poco.

Shelley soportaba la ironía de Hogg: pero la de su mujer lo irritaba. El espiritu de Hogg era un universo diferente del suyo y èl lo admitia como diferente. El de Harriet era su obra; él la habia formado, educado, cultivado: estaba hecho a sentirla como un eco suyo. Al descubrir de pronto que esa parte de sí mismo se había despegado y a veces sonreía escuchándolo: sintióse horriblemente triste.

Nada presenta más la apariencia de la tonteria que los celos inconfesados. En vez de atacar francamente al adversario. lo que seria natural y aun conmovedor. se critican con acritud palabras inolensivas, acciones banales y lo que es en realidad un sentimiento vivo y legítimo toma así el aspecto de una mezquindad insoportable. Harriet lo encontraba todo mal en Blacknell, porque estaba justamente celosa de Cornelia Turner. Pero Shelley, que atribuía su aire burlón y sus pullas vulgares a una increible puerilidad, le demostró una frialdad despreciativa.

Inmediatamente, por soberbia. Harriet acentuó su actitud. EEliza tiene razón - pensaba - es egoista y se cree admirable... Porque le gustan la vida retirada. las discusiones inútiles y los poemas italianos querría imponérmelos. ¿Con qué derecho me prohibe tener mis gustos personales? ¿Por qué la vida de una Cornelia que lee a Petrarca sería superior a la mía? Esas mujeres a quienes tanto admira son menos jóvenes y menos bonitas que yo... Muy luego sentiría $\mathrm{m}^{\mathrm{i}}$ ausencia....

Anunció la intención de reunirse con Eliza en Londres. Sólo insistieron para retenerla lo que exigia la politica.

-El pobre Shelley-pensaban las señoras Boinville-no tiene la mujer que necesitaria.

Tomó, pues, la costumbre de dejarlo en Bracknell y de pasar largas temporadas en Londres. Muy luego amigos oficiosos le contaron que la veian muy seguido con el Mayor Ryan.

Por vez primera, después de su matrimonio, ocurriósele a Shelley la idea de la infidelidad. Era un tema que siempre habia considerado con el mayor desprecio. en abstraclo. Al pensar bruscamente en Harriet y él como personajes posibles de esa tragedia experimentó el más violento dolor.

La razón le decía que debía sentirse feliz de librarse de una mujer mediocre. Si experimentaba amor zno era más bien hacia la deliciosa Cornelia Turner que hacia Harriet, cuya rencorosa vulgaridad lo había irritado tanto en Bracknell? Y si no la amaba ya ¿no era la ruptura la más simple de las soluciones? ¿No enseñaba èl que cuando el amor se extingue cada esposo debe recuperar su libertad? Pero en vano se repetía esos argumentos tan razonables. Descubría con estupor que Harriet Westbrook y Percy Shelley no eran ya dos seres aislados y libres. Parecía que los recuerdos, las caricias, los sufrimientos los hubieran envuelto 
en una red invisible y carnal que resistía dolorosamente a los esfuerzos por romperla.

Acudió a Londres resuelto a acusarse y excusarse. Pero encontró a Harriet rigida e irónica, impenetrable a loda conversación intima. Semejante cambio le pareció falal.

Esa niña suave, obediente y duice tres meses atrás se había puesto seca y altanera. Por momentos, Shelley creia divisar detrás de la máscara de orgullo una imagen fugitiva de la antigua Harriet; pero si insinuaba entonces una frase tierna estrellábase contra la fría coraza.

Errando al azar por las calles de Londres, pensaba:- Qué loco he sidol Unirme para siempre a una mujer que no me ama, que no me ha amado nunca... Ahora veo claro que se casó conmigo por mi forfuna y mi lítulo. Ve sus esperanzas perdidas y me hace pagar sus decepciones...-Y repetia interiormente:- Un corazón como un bloque de hielo... como un bloque de hielo...

Acaso si se hubieran hallado solos habria logrado recuperarla: pero entre ellos alzábasc Eliza, hostil, formidable, y el galante mayor Ryan entre bastidores, siempre listo para compadecerla por las injusticias de un marido doctrinario.

Después de algunos días de lucha. el ardor de Shelley se extinguió bruscamente. Era capaz de accesos de energía moral en que nada le parecía imposible; pero lo mismo que, en Oxford, después de sus paseos caía en invencible modorra, su volunlad moribunda semejaba una llama que lanza un resplandor prodigioso antes de desaparecer.

Cuando vió que Harriet seguia insensible, abandonó todas las esperanzas de salvar los restos de su hogar y anunció que se iría a Bracknell, solo. por un mes. Comprendia que después de tal ausencia la habría de hallar completamente transformada por su abominable ambiente, esperaba que después del delicioso intermedio campesino sobrevendría la calástrofe: pero se sintió demasiado débil para seguir luchando.

No soy-decia-sino un insecto que se calienta un poco jugando en un rayo de sol: la próxima nube me precipitará para siempre en el infierno y en el frío. Y recitaba melancólico la estrofa de Burns:

La dicha se parece a las flores de los campos

que mueren en las manos que las cogen,

o bien a la nieve de los prados. un momento blancas, luego inexistentes...

Pareciale que en la cristalina mansión de su pensamiento. Harriet, su hija y Eliza habian caído como trozos de materia viva y rebelde. En vano, con todas las fuerzas de la lógica, quería arrancarlas: la pesada realidad quebrábale esas armas ligeras. 


\section{XVI}

A veces, pensando en el lindo, pueril rostro de su mujer de 18 años, creía Shelley que aun sería posible reconquistarla y en un poema melancólico expresó con ternura este pensamiento. ¿Lo advirtió ella? El no lo supo. Encerrada cada vez más en su misterio hostil, cuando él regresó a Londres, partió ella para Bath.

El hubo de quedarse en Londres, esperando los 21 años, con el temor de que su familia quisiera quitarle sus derechos. Además, aunque cargado de deudas, empeñábase en pagar las de los otros y le parecia indispensable socorrer a Godwin, que necesitaba tres mil libras para no quebrar. ¿Cómo conseguirlas? En cuanto se habia planteado este problema, el filósofo demostró de nuevo vivo interés por Shelley y lo inviló con mayor frecuencia a su casa.

El joven aceptó, pues esperaba trabar conocimiento con la hija mayor de Godwin, Mary Wollstonecraft, que regresaria de Escocia. Godwin se la retrataba con caracteres seductores: diecisiete años, inteligencia activa y aguda. gran deseo de aprender, una perseverancia invencible. Ya Fanny y Jane se la habian descrito en parecidos términos, declarándola igual a su madre, la primera mujer de Godwin: Mary Wollstonecraft inspiraba a Shelley grande admiración y sentiase emocionado ante la proximidad de la desconocida.

Experimentaba la necesidad de encarnar en un bello rostro las fuerzas misteriosas y benévolas que creía esparcidas en el universo: el amor era para él una admiración apasionada, un acto de fe total, una mezcla exquisita y perfecta de inteligencia y sensualidad.

Si Mary no hubiera sobrevenido. o si lo hubiera decepcionado, sin duda aquel sentimiento suyo se habría dirigido a Fanny o acaso a Jane; pero Mary resultó la que èl aguardaba.

Tenia el rostro puro. fino y pálido. los cabellos blondos peinados en bandós. alta la frente, los ojos obscuros. graves, dulces. En aire de inteligencia dolorosa, de valor y orgullo, inspiró inmediatamente a Shelley el entusiasmo que le producían la lectura de Homero y Plutarco. Pareciale descubrir algo de heroico en esa niña delicada y la mezcla de feminidad y heroismo era la que más lo conmovía.

- Cuánta seriedad y cuánta emoción. pensaba èl. escuchando extático la voz juvenil. Una muchacha bella y pensadora, a esa edad deliciosa en que se juntan la gracia de la mujer y la ardiente curiosidad intelectual del efebo, constituian para él la obra de arte más exquisita. Inmediatamente experimentaba el deseo de hacer brillar esos ojos ávidos con la sorprendente visión de una aérea cabalgata a través de la metafisica. Harriet Westbrook realizaba imperfectamente su ideal. Un instante pudo forjarse la ilusión de que reunia ese encanto de la belleza y la inteligencia. Pero Harriet no resistió a la difícil prueba del tiempo. Le faltaba fondo: aun cuando fingia interesarse por las ideas, el vacío de su mirar la denunciaba. Era coqueta, frivola. hábil en pequeñas intrigas propias de mujeres y ello solo habria bastado para helar el entusiasmo de Shelley. 
Mary, con sus ojos de avellana, era fina y recta como una espada. Educada por el autor de la Justicia Politica, carecia de toda superstición y la nitidez aguda de su acento lo revelaba con elegancia. Todas las noches. comiendo en la casita de la calle Skinener, Shelley pasaba las horas contemplando su rostro. Hacía ademán de oir a Godwin que exponía el lamentable estado de sus negocios, discutia los presupuestos de Inglaterra o las leyes sobre la prensa: pero los ojos se le iban sin cesar.

También ella estaba pronta para amarlo. Sus hermanas habian preparado románticamente el camino con sus cartas en que no le hablaban sino del bello poeta y las descripciones resultaron inferiores a la realidad.

Lo encontró más admirable aún y encantador de lo que le habian dicho y vió en el acto que ella le interesaba. Aun cuando nunca se quejara, lo sintió triste. Una noche, solos en presencia del retrato de su madre. Mary le habló de sus pesares intimos. Adoraba a su padre. pero odioba a su madrastra. Y a causa de ella la casa se le habia hecho aborrecible. El único sitio del mundo donde se encontraba libre y protegida era la tumba de su madre y allá iba a leer y a meditar. Shelley. muy emocionado le pidió permiso para acompañarla.

Así, al cabo de cinco años, encontróse de nuevo en el cementerio con una virgen seria y apacionada. Una vez más lo divino encarnaba en una mujer. Pero lay! Shelley ya no era libre. Sentiase atraido hacia ella por una fuerza irresistible, deseaba tomarle la mano y besarle la boca de arco fino y perfecto; pensaba que ella abrigaria iguales deseos y sus ojos se apartaban. ¿Qué podia ofrecerle él? Era casado. Sin duda el matrimonio le parecia un simple convencionalismo y. no amando ya, debia disolverse. Nunca prometió otra cosa a Harriet; por lo demás, la creía en amores con el Mayor Ryan y no experimentaba escrúpulos. Pero siendo su matrimonio legalmente indisoluble ¿qué podia ofrecer a Mary? ¿Podia aceptar para ella la vida que rehusó imponer antaño a Harriet?

Sin embargo, un amor compartido, aunque sin esperanza, valía más que la duda y la soledad del alma. Resolvió decir a Mary la verdad de su matrimonio. El amor conyugal, aun moribundo, se defiende largo tiempo contra el destino con una coraza de silencio. Un dia llega en que el hombre experimenta la dolorosa alegria de mostrar sus llagas. Shelley describió a Harriet tal como ahora la veía y por una involuntaria trasposición dió a sus decepciones motivos de orden espiritual. Necesitaba una compañera capaz de comprender la poesia y la ciencia: Harriet era incapaz de lo uno y lo otro.

Dió a Mary un ejemplar de La Reina Mab. El volumen estaba dedicado a Harriet, inspiradora de sus cantos. Bajo la dedicatoria impresa, escribió:

.El Conde de Slobendorf estaba a punto de casarse con una mujer que, atraida solo por su fortuna, probó su egoismo abandonándolo en su prisión. .

Mary, al regresar a su casa con el presente, agregó:

.Este libro es sagrado para mí, nadie más lo abrirá para que yo pueda escribir en él lo que me plazca. Pero ¿qué dirée Que amo al autor más allá de lo que puedo expresar y que todo me separa de él, mi único y más ardiente amor. Por 
este amor que nos hemos consagrado, no puedo ser de ti, no puedo ser de otro. pero soy tuya, exclusivamente tuya...

Por el mudo beso, la mirada invisible,

la sonrisa oculta a los demás...

Me he consagrado a ti y este don es sagrado...

Esas miradas que nadie más vería, esas sonrisas que no comprenderán los demás. Godwin sin embargo les habia visto y adivinado. La intriga de su hija con un hombre que no era soltero le pareció inquietante. Le mostró el peligro y le rogó que no viera más a Shelley. A él le escribió en el mismo sentido. pidióle que se reconciliara con su mujer y que no volviera hasta una vez calmadas sus pasiones.

Esta prohibición, benévola sin embargo, desencadenó acontecimiento que, de otro modo. talvez se habrian hecho esperar. Shelley, apasionadamente enamorado de Mary. decidió huir con ella. No tenia ningún remordimiento por causa de $\mathrm{Ha}$ rriet a quien, a pesar de las afirmaciones de Peacock y Hogg. persistia en ereer culpable: Una sola cosa le interesa-decia:-el dinero... Arreglaré su situación en este punto y se sentirá feliz de recuperar su libertad. La llamó a Londres para notificárselo. Acudió; estaba en cinta de cuatro meses. Cuando su marido le anunció. con calma y bondad, su propósito. diciéndole que siempre seguirian siendo amigos, cayó peligrosamente enferma.

Shelley la cuidó con una abnegación que la hizo aun más desdichada. En cuanto la vió restablecida, siguió inflexible sus racionamientos. La unión de los sexos es santa mientras contribuye a la dicha de los cónyuges y queda disuelta en cuanto los males superan a los bienes. La constancia no tiene nada de virfud por si misma: participa aun del vicio cuando tolera defectos a veces considerables en el ser elegido.

Cuando él desplegaba en torno suyo esa red inflexible, transparente e infranqueable. Harriet sentiase perdida. Como antes, cuando habia querido defenderse contra sus argumentos anti-religiosos, ahora se encontraba débil e incapaz. Presentia que habia una respuesta. que ese inmenso dolor, esa angustia, esa mezcla de amor y de honor tenían una palabra y la habria hallado con el espiritu más sereno: pero no lo encontró nunca. Dareciale debatirse en medio de murallas invisibles y aplastantes.

Para desahogarse lanzaba terribles injurias contra Mary, culpándola de haberlo maquinado todo. de haberle quitado a Shelley, especulando con su amor al romanticismo, arrastrándolo a esas citas en la tumba de su madre, cuya memoria profanaba.

Mary por su parte se habia forjado una imagen odiosa de Harriet. Una mujer que habia tenido la suerte de casarse con Shelley y que era incapaz de hacerlo feliz tenia que ser forzosamente egoista. futil y mediocre. Sabia que él la trataria generosamente, que preparaba una donación en favor suyo. que ordenaría a su banquero pagarle mayor parte de su pensión y ello le tranquilizaba la conciencia. Tendrá dinero y quedará contentas pensaba con desprecio. 
Shelley, nervioso. agitado, cuando veía a Harriet caer en accesos de desesperación conmovedores y torpes no podia olvidar un pasado encantador. Al volver junto a Mary la adoraba por gracia grave. A fin de calmarse. comenzó a tomar láudano en dosis cada vez mayores. Repetia a sus amigos el verso de Sófocles:

No haber nacido eso se llama ganar la partida: pero una vez en el mundo el mejor camino, con mucho, que puede tomarse es volverse lo más luego posible al sitio de partida.

\section{XVII}

La silla de posta estaba pedida para las cuatro de la mañana: Shelley veló toda la noche frente a la casa de los Godwin. Al fin palidecieron las estrellas y las lámparas. Mary. vestida de viaje. entreabrió sin ruido la puerta. Jane Clairmont que a última hora resolvió partir con su hermana, preparaba las maletas en silencio.

El viaje fatigó mucho a Mary; pero Shelley no se atrevió a detenerse temiendo la persecución de Godwin. Por último, a las cuatro de la tarde. llegaron a Douvres y. tras algunas discusiones con los empleados de la Aduana. consiguieron una pequeña embarcación para Calais.

Bella la tarde; las blancas rocas de la costa disminuian lentamente: los fugitivos se sintieron salvas. Luego se levantó la brisa. infláronse las velas y corrieron por el mar. Mary. muy enferma, pasó la noche sobre las rodillas de Shelley, que la sostenía con dificultad. Descendió lentamente la luna sobre el horizonte: después, en la total obscuridad, estalló una tormenta y los relámpagos iluminaban a trechos el mar. Apareció por fin la aurora, calmóse el viento y los fugitivos vieron salir el sol en la costa de Francia.

En las calles de Calais, la alegre agitación del puerto. la lengua extranjera. las costumbres pintorescas de los pescadores reanimaron un poco a Mary. Pasaron el dia en la posada, porque habia que esperar las maletas. Con ellas llegó $\mathrm{Mr}$. Godwin y sus anteojos verdes. La gorda señora esperaba llevarse por lo menos a Jane; pero la elocuencia de Shelley la venció y hubo de regresar sola. A las seis los viajeros se encaminaron a Boulogne.

He aquí, pues, a Shelley con su nueva esposa peregrinando por los caminos de Francia. Se notará que en estas escapadas románticas no puede prescindir de la hermana de la bien amada.

En 1814 los caminos de Francia no ofrecian mucha seguridad. Soldados 
merodeadores desvalijan a los viajeros. Para llegar a Suiza, Shelley compra un burrito tan pequeño que, a veces. con Jane, tenian que llevarlo de la brida.

Quiso fijar su residencia en Brunnen, sobre el lago de los Cuatro Cantones. cerca de la capilla de Guillermo Tell. defensor de la libertad; pero al cabo de dos dias una terrible nostalgia lo oprime y levanta su tienda. Dor Lucerna. Bale. Colonia y Rotterdam, a pie cuando carecen de dinero, en diligencia o barca, vuelven a Londres.

Godwin cierra su puerta al trio: encuentra que Shelley aplica demasiado bien los principios de la Justicia Politica. Harriet, la esposa legitima. contrae deudes y forma escenas a Shelley. Le da, además. un segundo hijo... Jane decide llamarse en adelante Clara; lo encuentra más bonito. Como Eliza, corteja púdica y misteriosamente a Shelley... Estos amores de hermanas parecen obedecer a un rifmo... Hogg. el inmoral y encantador Hogg. es admitido de nuevo en el hogar de su amigo... El dinero falta siempre. La prisión por deudas amenaza a Shelley.

\section{XVIII}

En Enero de 1815. esta existencia dificil se vió trasformada por un acontecimiento largo tiempo esperado: el viejo sir Bysshe murió a los 83 años de edad. $\mathrm{Mr}$. Timothy heredó el título de baronet y Shelley se convirtió en el inmediato heredero.

Partió para la casa de su padre. seguido de Clara. La dejó en la ciudad y se presentó solo en casa de su padre. Sir Timothy, inflado con su nuevo título y más furioso que nunca de que un baronet pudiera tener hijo semejante. le hizo cerrar la puerta por un lacayo. Shelley se sentó en las gradas del umbral y se puso a leer a Milton. en espera de noticias. Luego salió el doctor para decirle que su padre estaba muy ofendido, luego Sydney Shelley visitó a su vez furtivamente al hijo maldito para darle detalles sobre el testamento.

Era un documento extraordinario. La idea fija del viejo era constituir una enorme fortuna hereditaria y acrecentar el mayorazgo en todo lo posible. Dejaba doscientas cuarenta mil libras, de las cuales ochenta mil pertenecian necesariamente a Percy una vez muerto sir Timothy. El resto quedaba libre. Pero sir Bysshe deseaba que se uniera a las ochenta mil para formar un bloque enorme trasmisible de primogénito en primogénito a los barones Shelleys del Porvenir. Para ello se necesitaba el consentimiento y la firma de su nieto y había esperado comprarlas de la siguiente manera: si Shelley consentía en prolongar el mayorazgo tendría el usufructo de toda la fortuna: en caso contrario sólo heredaria (después de la muerte de su padre) las ochenta mil libras que no le podian quitar.

Shelley regresó a Londres meditando sobre esta extraña sifuación y para disculirla con su abogado. Estimaba que no debía cooperar a la prolongación del mayorazgo, puesto que desaprobabe toda esa legislación plutocrática; por lo demás no queria para él ni para sus hijos el goce de una inmensa fortuna. Lo que deseaba era tener inmediatamente una renta para vivir según sus gustos y una pequeña suma 
para sus deudas. Propuso a su padre la venta de sus derechos por una pensión que se le pagaría en el acto. Esta combinación gustó a sir Timothy que, perdida toda esperanza de regenerar a Percy, sólo pensaba en su segundo hijo: por desgracia los abogados no creyeron posible la transacción a causa de los términos del testamento. Autorizaron solamente la reventa por Shelley a su padre de una herencia de un fío abuelo. mediante la cual Shelley quedó en posesión de mil libras anuales. No era la gran fortuna, pero era el término de la miseria, de las piezas amobladas y las amenazas de la justicia.

Su primer pensamiento fué poner una pensión a Harriet. Le prometió doscientas libras anuales que, agregadas a lo que le daría su padre, bastarian para su sostenimiento. Luego quiso pagar las deudas de Godwin y empeñó en ello todo el primer año de sus entradas.

Su venerable amigo encontró que mil libras eran mucho menos de lo que esperaba. A su juicio nada más fácil que obtener. con la garantía de una herencia próxima, los varios miles que necesitaba su empresa editorial para ponerse al dia. Shelley. exasperado, pero político, demostró una imperceptible indignación viendo al padre de Mary escribirle al raptor de su hija para pedirle dinero y negarse al mismo tiempo a mantener con ellos toda otra clase de relaciones. A lo que Godwin repuso que justamente por que le pedia dinero no podia recibir a Mary: su dignidad se oponía. No queria exponerse a que el mundo dijera que había vendido el honor de su familia para pagar sus deudas. Ton exigente se demostró en sus escrúpulos que devolvió a Shelley un cheque a su nombre, observándole que esos dos apellidos, Godwin y Shelley, no podian figurar juntos en el mismo documento. Que Shelley girara a la orden de Mr. Smith o Mr. Hume y entonces él. Godwin, podría cobrarlo.

\section{XIX}

El hijo de Mary nació antes de tiempo y los médicos dijeron que no viviría. Su padre veló entre la cuna y el lecho, en compañia de Séneca y Tito Livio. Fanny les llevó una carnisita de parte de Mrs. Godwin: pero el filósofo permaneció inflexible. Hogg acudió a charlar. a comentar la gran noticia del día, el reforno de la isla de Elba, y animó a Mary con su buen sentido irónico. Acompañada siempre de Shelley. y todavia afiebrada. solia experimentar la impresión suave y algo aterrante de evadirse de la tierra y de la vida. Hogg era más sólido.

A pesar de las predicciones, el niño creció, vivió un mes y cuando comenzaban a estar tranquilos, una mañana, al despertar, lo hallaron muerto.

Shelley y Clara seguian vagando por Londres: Mary quedábase sola en casa. cosiendo y pensando en su hijito. Era madre y ya no lo soy, deciase y en la noche soñaba que el nin̄o no habia muerto y que, friccionándolo, conseguian reanimarlo. Despertaba: la cuna estaba vacía. Se escuchaban en la calle rumores y gritos de muchedumbres agitadas. Eran tiempos de conmociones populares y de Francia llegaban amenazas de guerra. Mary tenía siempre un velo de lágrimas sobre los ojos. La presencia de Clara en la casa la molestaba cada dia más. Estaba segura de 
que Clara habia amado siempre a Shelley y seguía amándolo. La lealtad de Percy le parecia evidente y su moralidad más angélica que humana; pero encontraba natural leer a Petrarca en compañia de una joven apasionada y velar noches enteras a su lado. Es que-pensaba-mi encantador Shelley conoce más a los ellos que a las mujeres:.

De noche, sola con él, confesábale sus celos. El no comprendia bien tal sentimiento. que juzgaba bajo y que disminuía a su divina Mary. Pensaba que su capacidad de amar no tenía limites y no quilaba nada a su amante con proteger a Clara. La compañia de aquel ser brillanie y salvaje le gustaba mucho: pero al cabo hubo de reconocer que la atmósfera de su triple hogar se ponía irrespirable.

Mary le suplicó que alcjara a Clara, a quien daba siempre el nombre de esu amiga. Le buscaron mucho tiempo un puesto de instifutriz o dama de compañia: pero la extraña reputación que les había dado su fuga a Francia dificultaba toda colocación.

Por lo demás. Clara no se empeñaba mucho en irse. Complaciase en esa intimidad intelectual y esperaba sin pavor sus necesarias consecuencias. Por fin la dulce firmeza de Mary venció y quedó resuelto que Clara se iria adonde una viuda. amiga de Godwin.

Diario de Mary.-No muy contenta.-Después de almuerzo, lectura de Spencer. Shelley sale con su amiga. Vuelve. Traducción de Ovidio: 90 líneas. Llega Hogg: le leo mi Ovidio. Shelley y la dama salen. Después del té, última conversación de Shelley y su amiga.

Sábado.-Clara parte. Shelley la acompaña. Hogg viene a las cinco. Inquieta de que Shelley no regrese, salgo a encontrarlo. Llueve. Vuelve a las seis treinta. El asunto está terminado. Lectura de Qvidio. Charles Clairmont nos acompaña a tomar té. Se habla de cuadros. Comienzo otro diario con nuestra regeneración.

Clara desterrada en el campo gustó algunos dias esa gran calma después de un periodo tempestuoso: pero la muchacha no era para contentarse con la soledad campestre y buscó y encontró luego una razón de vivir.

Los enamorados creen siempre que su amor nace de haber enconcontrado a un ser excepcional. La verdad nos enseña que el amor preexistente busca por el mundo su objeto y lo erea si no lo halla. Sólo que esta investigación, inconsciente en los tímidos, en la audaz Clara fué enteramente lúcida y cuando comprendió que no le quedaba ninguna esperanza de arrebatarle el marido a su hermana, ni aun de compartirlo con ella, buscó deliberadarnente otro héroe a sus sentimientos sin empleo. Sola en el campo, no podía descubrirlo cerca de ella. En situación parecidas. ofras escriben a los grandes soldados, a los grandes actores. Era cultivada y buscó un poeta.

No encontró ninguno más digno de ella que Jorge Gordón, lord Byron, enfonces el hombre más admirado y más aborrecido de Inglaterra. Sabía de me- 
moria sus poemes, que Shelley leía con frecuencia en alta voz con entusiasmo. Sabia la maravillosa historia de aquel dia en que Lord Byron, desconocido la vispera, despertó célebre por haber publicado Childe Harold, y también la leyenda de vicio, de ingenio. de encanto diabólico y de infernal crueldad formada en torno a su nombre.

La belleza del hombre, la grandeza del fitulo, el genio del escritor, la audacia de las ideas, el escándalo de los amores, todo se juntaba en él para formar al perfecto héroe. Habia tenido queridas nobilisimas; la condesa de Oxford. Lady Frances Webster. y esa encantadora Lady Carolina Lamb que, el dia de su presentación, escribió:- Loco, malvado. peligrosos. Y luego: „Pero este bello rostro pálido encierra mi destinos.

Casado, todo Londres sabia que entrar en la carroza de novios, después de la ceremonia nupcial, habia dicho a Lady Byron:- . Sois mi mujer: esto basta para que os odie: si fuerais la de otro os podria amar. Y la trató con tal desprecio, que ella pidió el divorcio al cabo de un año. Los murmuradores de profesión afirmaban que habian descubierto relaciones incestuosas entre Byron y su hermana Augusta. Desde que se echó a correr esa sombría historia las almas timoratas se apartaban de Byron con horror.

Clara amaba las dificultades y tenía confianza en su genio; se procuró la dirección de don Juan y resolvióse tentar suerte:

\section{Clara a Byron}

Una extranjera se permite escribirle. No imploro su caridad, porque no la necesito absolutamente: pero tiemblo al pensar en la posible suerte de esta carta. ¿Si Ud, viera en mi una importuna dquién podría reprochárselo? Le parecerá talvez extraño. pero es cierto, no obstante, que mi dicha está en sus manos. Si una mujer de fama inmaculada, que no depende de padre ni marido, se entrega a su discreción, si esta mujer le confiesa, con el corazón palpitante. que lo ama desde hace muchos años, si le garantiza el secreto y la seguridad, si está pronta a pagar su benevolencia con un afecto y una abnegación sin limites cla traicionaria Ud. seria mudo como la tumba?... Quiero que me conteste Ud. sin dilación: escribame a E. Trefusis, Nolcy, Place. Marylebone.

Don Juan no contestó. La desconocida del estilo pomposo era una flaca presa para el noble Lord. Pero chay algo más tenaz que una mujer cansada de la virtud? Clara atacó por segunda vez: Se ruega a Lord Byron decir si podrá. hoy a las siete, recibir a una dama que desea comunicarle algo muy importante y que querria ser recibida sola y en el mayor secreto. Lord Byron hizo responder por medio de su criado que no se encontraba en Londres.

Entonces Clara escribió con su propio nombre: quería entrar al teatro. sabía que Lord Byron tenía influencias en Drury Lane y solicitaba un consejo. Esta vez Byron respondió aconsejándole que se dirigiera al director. Sin desalentarse, operó ella un cambio de frente muy ingenioso: no era de teatro sino de literatura 
de lo que se trataba: habia escrito media novela y deseaba someter a su ensayo a Lord Byron. Como este confinuaba silencioso e inaccesible, Clara arriesgó la oferta precisa ante la cual ningún hombre dolado de un poco de amor propio resiste:

\section{Clara a Byron}

Puedo parecerle imprudente, viciosa, pero el tiempo le demostrará que lo amo a Ud. con dulzura y constancia y que soy incapaz de astucia y de malos manejos.... Le aseguro a Ud. que su porvenir será para mi idéntico al míol

¿Tiene algunas objeciones que ponerle al siguiente plan? Salgo con Ud. una noche en diligencia hasta diez o doce millas de Londres. Alli estaremos libres y seremos desconocidos. Ud, regresará al ofro día, por la mañana temprano. Arre. glaremos las cosas de tal modo que no se sospeche nunca nada. ¿Quiere Ud. admitirme en su vida un momento? ¿Dónde? No me quedaré un segundo después que Ud, me haya dicho que parta. Haga Ud. en seguida lo que guste; no me vea más. tráteme con dureza; no recordaré sino la gracia que Ud. me habrá olorgado y la salvaje originalidad de su actitud....

Al fin don Juan, fatigado, hostigado por la interminable persecuciōn, resolvió ceder a su conquista. Además al dia siguiente se iba en viaje a Suiza e Italia.

\section{$\mathrm{XX}$}

Pero don Juan no contaba con la energía de Elvira. Clara resolvió seguirlo al continente y esa muchacha aceitunada era una fuerza de la naturaleza. Emprendió la tarea de hacerse acompañar por Shelley, a quien veía dispuesto a salir de Inglaterra.

Desde que ella había abandonado su casa. habianse instalado ellos al borde del Támesis, cerca de Windsor. Bajo las encinas del parque. Shelley compuso su primera grande obra después de La Reina Mab. Era, como todos sus poemas. una autobiografia traspuesta: pintaba a un joven ardiente, vencido por la realidad, sin las afirmaciones cortantes de su primera época, más bien con una resignación melancólica.

Pero aunque nada lamentaba del pasado. la parmanencia en Inglaterra se le hacia intolerable a causa de la situación irregular de Mary y pensó que lejos. donde su aventura era desconocida, tendría más probabilidades de hallar amigas $y$ un poco de paz.

Les había nacido un segundo hijo, sano y robusto; los gastos aumentaban; la vida en Suiza era más barata. Clara no necesitó grandes esfuerzos para decidirlos a efectuar el viaje.

Como en su primera fuga, pero más confortablemente, el extraño trío cruzó Paris, la Borgoña, el Jura y fué a instalarse en el Hotel Inglés de Sécheron, ba- 
rrio de Ginebra. El hotel estaba a orillas del lago: desde las ventanas se veian centellear al sol las crestas de las pequeñas olas azules y bajo un velo de aire luminoso temblaba la línea sombría de los montes. Más lejos. picos blancos, irreales, como nubes sólidas, brillaban. Escapados al invierno de Londres, esos paisajes de sol les parecian deliciosos. Arrendaron un bote y pasaban días enteros sobre el lago, leyendo, durmiendo.

Mientras la infantil caravana vivia olvidada entre el cielo y el agua, a través de las planicies de Flandes. Childe-Harold iba hacia ellos con un equipaje suntuoso. Inglaterra, en una de esas crisis de incoherente virtud que suceden en ella a la más sorprendente tolerancia, acababa de arrojar a Lord Byron, acusado de incesto. A su entrada en un baile vió a todas las mujeres huir, como si se tratara del demonio en persona. Decidió abandonar para siempre esa patria hipócrita.

La más apasionada curiosidad rodeó su partida. El mundo, que tan duramente castiga las rebeldias del instinto. las envidia en el fondo y las admira. En Dover, cuando el peregrino se embarcó, dos filas de espectadores bordeaban el puente: muchas damas de sociedad se habian disfrazado de mujeres del pueblo para mezclarse a la multitud. Se mostraban las enormes cajas que contenia su canapé, su biblioteca, su vajilla. El mar estaba malo y Lord Byron recordó a sus compañeros que su abuelo, el Almirante Byron, era conocido en la armada con el nombre de Jack el de la Tempestad. porque nunca podia embarcarse sino durante una borrasca. Contemplaba con cierta complacencia ese fondo sombrio de su destino familiar. Desdichado, gustábale que sus desdichas fueran grandes.

Algunos dias después una extraordinaria actividad se manifestó en el holel de Sécheron; la llegada del noble Lord producia un trastorno. Clara estaba conmovida a pesar de su audacia: Shelley impaciente por conocer al gran poeta. La acusación de incesto, las relaciones con Clara no podian chocarle. Esperaba que se formaran entre su cuñada y Byron los mismos lazos que lo unian a él con Mary y en cuanto al incesto no veia ningün inconveniente en que un hermano amara a una hermana. Si las leyes lo prohibían. era por una de esas fantasias absurdas en que las sociedades se complacen. Aun el tema pareciale uno de los más poéticos que pudieran cantarse. Mary. por su parte, sentiase feliz de ver a Clara fuera de combate. aunque en condiciones algo peligrosas.

La primera aparición de Byron no decepeionó a los Shelley. La belleza de aquel rostro impresionaba. Desde luego el aire de orgullo e inteligencia, una palidez de claro de luna en la que resaltaban espléndidos los ojos de terciopelo, animados y sombríos, los cabellos negros, algo rizados, la línea perfecta de 
las cejas. La nariz y el mentón eran de un dibujo firme y gracioso. El único defecto de aquel bello sér aparecia al andar. Cojo. decian; pie de fauno, insinuaba él. que prefería ser diabólico antes que enfermo. Mary observó en el acto que esa claudicación la daba una gran timidez; cada vez que tenia que dar un paso delante de espectadores, lanzaba una frase satánica. En el registro del hotel, frente a la palabra .edad. escribió ecien años.

Los dos hombres se avinieron: Byron encontraba en Shelley a un joven de su clase que, a pesar de su vida dificil, conservaba la encantadora soltura de los muchachos de buena sangre. La cultura de aquel espiritu lo admiró: él mismo habia leido mucho, pero sin esa extraordinaria seriedad. Shelley habia querido saber. Byron deslumbrar: y luego lo advirtió. También sintió que la voluntad de Shelley cra una fuerza pura y tensa. mientras que la de él flotaba al azar de las pasiones y de las queridas.

Shelley. modesto. no vió esta admiración que Byron ocultaba con grande esmero. Oyendo el tercer canto de Childe-Harold se sintió conmovido y descorazonado. En esa fuerza, en ese ritmo potente, en ese movimiento de ola irresistible que sube reconoció el genio y desesperó de igualarlo.

Pero si el poeta le causó entusiasmo, el hombre le produjo gran sorpresa. Byron desafiaba las prejuicios y creía en ellos. Los encontraba en el camino de sus deseos y los atropellaba, pero con remordimientos. Lo que Shelley habia hecho ingenuamente, él lo hacía a conciencia. Expulsado del mundo. sólo gustaba de los éxitos mundanos. Mal marido, no respelaba sino el amor legitimo. Lanzaba paradojas cinicas por represalia, no por convicción. Entre la depravación y el matrimonio no concebia término medio. Trató de aterrar a Inglaterra desempeñando un rol audaz, pero por desesperación de no haber podido conquistarla en algún cargo tradicional.

Shelley buscaba en la mujer una fuente de exaltación. Byron un pretexto para reposar. Shelley, angélico, demasiado angélico, las respetaba: Byron humano, demasiado humano, las deseaba y hablaba de ellas con el mayor desprecio. Decía: Lo que tienen de espantoso es que no se puede vivir con ellas ni sin ellas,. Y agregaba: $\mathrm{Mi}$ ideal consiste en una mujer con bastante inteligencia para comprender que debe admirarme, pero no tanto como para querer que la admiren a ellas. El resultado de las primeras conversaciones fué curioso: Shelley, mistico sin saberlo, chocó a Byron, don Juan a pesar suyo.

Esto no impidió que formaran una sociedad encantadora. Ambos amaban con locura la boga. Compraron un bole en sociedad y lodas las lardes se embarcaban con Mary. Clara y el joven médico Polidori. Byron y Shelley, silenciosos, dejaban caer los remos y seguian entre las nubes y los reflejos de la luna las imágenes fugitivas: Clara cantaba y su bella voz mecía los pensamientos en una cadencia voluptuosa por sobre las aguas estrelladas.

Una noche de gran viento. Byron, desafiando la tempestad, anunció un canto albanés: .Pónganse sentimentales - dijo- y préstenme toda su atención. Lanzó un grito ronco y prolongado y después soltó una carcajada. Mary y Clara, desde ese día, lo bautizaron el Albanés, y por abreviatura. Albés. 
Shelley y Byron hicieron juntos una peregrinación literaria en rededor del lago. Visitaron los sitios en que Rousseau sitúa La Nueva Eloisa: Clarens, el dulce Clarens ccuna de todo amor apasionado, el Lausanne de Gibbon, el Ferney de Voltaire. El entusiasmo de Shelley se comunicó a Byron, que bajo esta influencia compuso algunos de sus más bellos versos. Cerca de La Meillerie, una de esas violentas tempestades del lago Ginebra, puso en peligro la barca. Byron empezó a desnudarse. Shelley, que no sabía nadar, se quedó impasible. cruzado de brazos. Su valor aumentó el aprecío de Byron, pero siempre en silencio.

Fatigados del hotel. los Shelley arrendaron en Coligny un cottage al borde del lago: Byron se instaló algo más arriba. en la villa Diodati. Un viñedo separaba las dos casas. Una mañana, dos viñadores vieron a Clara salir corriendo de la villa Diodati y entrar a escape en la de Shelley. En la escapada perdió un zapato y no se atrevió a recogerlo. Los trabajadores llevaron irónicamente a la acaldia la pantufla de la señorita inglesa.

Sus amores no eran felices. Estaba en cinta y Byron. fatigado de ella. le hacia sentir con dureza su cansancio. Admiró un momento. acaso, su ingenio. su voz, pero se aburrió pronto. No se reconocia ningún deber para con esa muchacha que se le habia ofrecido tan a la fuerza: ¿¿Raplada? ¿Quién fué rapta. do en esta historia sino mi pobre, querida persona? Se me acusa de dureza con las mujeres: he sido siempre su victima... Desde la guerra de Troya nadie ha sido más raptado que yo....

Shelley discutió con él el porvenir de Clara y del niño. En cuanto a ella. el noble Lord sólo quería dejar de verla lo más pronto posible y para siempre. Shelley no podía combatir esta tesis. puesto que el amor sólo depende de si mismo. Pero defendió los derechos del hijo por nacer.

Byron tuvo primero la extraña idea de confiarlo a su hermana Augusta, a quien la voz pública lo unía escandalosamente. Clara rehusó y entonces prometió encargarse de él. pero sôlo desde la edad de un año y a condición de ser su único dueño.

Se hacia difícil para los Shelley continuar en su compañia. No porque los dos hombres hubieran reñido. Shelley halló penosa la cuestión, pero natural. Clara sufria y Mary solia indignarse de la actitud de Byron y de sus cínicas opiniones sobre la mujer. Por lo demás. de nuevo experimentaba el deseo nostálgico de ver los paisajes ingleses. Una casa junto a un río inglés apareciansele a la distancia como refugio delicioso. Shelley escribió a Peacock y Hogg que le arrendaran una y empezó el viaje de regreso.

Después de su partida. Byron escribió a su hermana Augusta:

No me hagas reproches. ¿Qué otra conducta podia observar? Una muchacha imprudente, a pesar de todo lo que hice y dije, me siguió o, mejor 
dicho. me precedió, puesto que la encontré instalada aqui y me ha costado un mundo convencerla de que se vaya. Al fin ha partido.

Ahora, querida mía, te confieso desde el fondo de mi corazón que no podía impedir los hechos y que hice cuanto estuvo de mi parte por terminar esta historia. No la amo y no tengo amor disponible para nadie: pero tampoco podia hacerme el estoico con una mujer que habia cruzado ochocientas millas para desfilosofarme... Ya sabes todo lo que hay..

Después de esta nueva vuelta a Inglaterra. las primeras sombras de su trágico destino empiezan a caer sobre Shelley. Apenas instalado en Bath, se suicida Fanny Imlay. la medio-hermana de Mary y Clara. Talvez amaba a Shelley en silencio y sin esperanza. Le escribia cartas dulce... La última. que dejó al lado del frasco de láudano. no contenia ninguna queja... Apenas repuesto de este golpe, Shelley, que hacía buscar a Harriet. pues no tenía noticias de ella, supo que su joven mujer. desesperada por el abandono de su marido, se dejó arrastrar primero por la mala vida y luego por la corriente del rio de Hyde Park, de donde la sacaron demasiado tarde. ILa madre de sus dos hijos! Y advièrtase que Shelley no era inconstante, sino que pretendia acumular. fotalizar sus amores. Asi, enemigo jurado del matrimonio, opresuróse, quince dias después. a casarse con Mary Godwin y reivindicar la tutela de sus niños Charles y Lanthe. El Lord Canciller se la negó en una sentencia muy humillante para Shelley. porque significaba en cierto modo un veredicto oficial de locura incurable.

Durante el proceso compró una encantadora casita en Marlow. Ariel consentia, por fin, en habitar una residencia humana. Una imponente galería fué trasformada en biblioteca y adornada con grandes reproducciones de Venus y Apolo. El jardin era vasto: una niñita de extraordinaria belleza jugaba con Willima y Clara Shelley. Era Clara Allegra, hija de Clara y de Byron. Su padre estaba en Venecia, divirtiêndose mucho. según decian.

No pasó mucho tiempo sin que los tres marcharan a reunírsele.

\section{$\mathrm{XXI}$}

Una vez más la caravana de los tres marchó hacia los paises del olvido y del sol; las niñas y las niñeras que ahora los acompañaban apenas estorbaban sus movimientos rápidos y caprichosos.

Por el Monte Cenis llegaron a Milán donde se detuvieron para avisar a Byron la presencia de su hija en Italia. Shelley pasaba los dias en la catedral. 
leyendo el Infierno y el Purgatorio. Amaba las tres ventanas góticas gigantescas que derraman en el coro su luz religiosa. Las iglesias no le inspiraban ya el mismo horror que antes: desde que habia sufrido se sorprendia de hallar en ellas. mejor que en cualquier sitio, un refugio digno de la grandeza de las pasiones humanas. Con Dante, en esa sinfonía de colores sombríos y cálidos, el catolicismo no le parecía invención de impostores.

La respuesta de Byron fué que no quería ver a Clara por nada del mundo y huiría de todas partes para no encontrarla: cuanto a la pequeña, aceptaba encargarse de su educación siempre que lo dejaran a él de único maestro. Shelley trató de obtener condiciones menos duras; pero Byron quería ante todo librarse de las escenas de Clara y no cedió un punto. Un Veneciano de paso por Milán refirió que el . Mylord inglés. llevaba en Venecia una vida escandalosa y mantenía todo un harem. Esto no dejaba de ser inquietante para la educación de Allegra y Shelley aconsejó a Clara renunciar a toda ayuda de Byron antes que confiarle la niña. Como siempre, él se encargaría de los gastos. Pero Clara era soberbia. Orgullosa del nacimiento de Allegra, quería que su hija disfrutara de sus ventajas: tenia plena confianza en Elisa, el ama de la chicuela, y resolvió enviarlas a ambas a Venecia. A pesar de las afectuosas advertencias de Shelley. Allegra fué entregada a su padre.

Luego recibieron noticias inquietantes. Byron sólo había alojado algunas semanas en su casa a la niña. Encantado de su belleza y de verla admirada y acariciada por los venecianos en la Piazzeta, luego se había cansado de ese juego monólono y la confió a la mujer del cónsul inglés. Mrs. Hoppner. ¿Quién era esta Mrs. Hoppner? ¿Cómo trafarian a la creafura? Elisa aseguraba que era una excelente señora: pero Clara empezó a sentir terribles remordimientos. Durante todo un año no había dejado a la niña: la adoraba; era el único ser en el mundo a quien pudiera llamar suyo. puesto que su familia la rechazaba y su amante no queria verla. Shelley se compadeció de su tristeza y ofreció acompañarla a Venecia: Mary, a pesar de su repugnancia a que viajaran juntos, consintió en que lo hiciera.

Para no irritar a Byron que había prohibido a Clara acercarse a cualquier ciudad donde él estuviera, resolvieron que ella esperaria en Padua el resultado de la embajada de Shelley: pero, tan cerca de su hija. la madre no pudo contenerse y pensó que ocultándose, podría visitarla sin peligro. Tomó con Shelley una góndola que descendía hacia Brenta, atravesaron la laguna de noche. en medio de una tempestad, mientras a lo lejos las luces de Venecia brillaban confusas, tras una cortina de agua.

Al dia siguiente por la mañana visitaron a los Hoppner, que los recibieron bondadosamente: la señora hizo llamar a Elisa y la niña. Allegra había crecido mucho: estaba pálida. menos viva que antes. pero siempre bellisima. Luego se habló largamente de Byron. Los Hoppner, buenas gentes, de moralidad tradicio- 
nal. pareja joven y enamorada. excitados por esas intrigas, algo humanizados también por la indulgente Venecia, contaban las cosas moviendo la cabeza.

Desde el tercer dia de su arribo. Byron se procuró una góndola y una querida. La querida era Marianna Segati, mujer de un comerciante en paños, que había arrendado unas piezas al poeta. Imprudente negocio; pero el paño se vendia poco. La mujer tenía veintidós años, ojos negros soberbios, una voz deliciosa. Aunque de condición burguesa, la aristocracia veneciana la recibía para oirla cantar. Que debia enamorarse del noble extranjero, bello, generoso y genial, era algo tan necesario como las reacciones químicas más simples. Cuanto el mercader de Venecia. Byron tenía el ducado listo y la moral del país permitia por lo menos un amante en casa.

Mrs. Hoppner, mujercita dulce, de ojos inteligentes, referia esta historia con el aire de tristeza y golosina con que las mujeres honradas hablan del vicio. Su marido. tras mil precauciones, agregó que eso no era todo. Se contaba en el pueblo que el señor inglés poseía, en algún barrio de la ciudad, una casa misteriosa donde, no bastándole una musa, reunía a las nueve hermanas. Toda una leyenda se formaba: los ingleses de viaje hablaban de Nerón y Heliogábalo. El pueblo admiraba y. bajo la máscara del carnaval, las mujeres se cogian del brazo de Byron. Estos relatos no eran tranquilizadores para Clara. Preguntó qué debia hacer: el cónsul le aconsejó no dejar ver a ningún precio que se encontraba en Venecia. pues Byron expresaba con frecuencia su gran temor de verla llegar.

A las tres de la tarde. Shelley visitó a su amigo en el palacio Mocenigo. Byron lo recibió en triunfo. Shelley era talvez el único hombre con quien consentía en hablar seriamente. de igual a igual. Aun cuando le explicaron el viaje de Clara y su objeto permaneció tranquilo y razonable. Dijo que comprendia muy bien los temores de Clara, que no podia devolverle a Allegra porque los venecianos, que ya lo acusaban de caprichoso, dirian que se había fatigado de la niña. pero que iba a reflexionar y descubriria un medio de conciliarlo todo. Luego propuso un paseo a caballo por el Lido.

A través de la laguna, la góndola los condujo hasta los caballos que esperaban en la larga playa medio sumergida, sembrada de cardos y de algas. A Shelley le encantaron esas arenas desiertas, ese galope en medio de las olas. Sólo la idea de que Clara, ansiosa. aguardaba en casa de los Hoppner amargó un poco su placer. Byron habló de la tonta actitud de los ingleses que llegaban a Venecia y lo perseguian con su curiosidad, pagando sirvientes para ver su dormitorio. Luego se refirió a las desdichas de Shelley con grandes protestas de amistad. -Si yo hubiera estado en Inglaterra había removido tierra y cielo para haceros devolver los niños.. Lo cual lo condujo a tratar de la maldad humana, que juzgaba infinita. Los hombres se odian unos a otros... Esperar o desear algo es señal de espíritu visionario.

- ¿Por qué?-dijo Shelley,-Ud. admite que el hombre sufre sus instintos sin dirigirlos. Mi fe es diversa: yo creo en la potencia de la voluntad.

Byron señaló la ciudad patricia que el sol poniente envolvia en púrpura sombria $\mathrm{y}$ oro en fusión. 
-Volvamos en góndola-propuso.-Tengo algo que mostrarle.

$\mathrm{Y}$ después que se hubieron deslizado algunos minutos sobre las aguas:

- Mire hacia el oeste y escuche. ¿No oye una campaña?

Shelley vió entonces, sobre una pequeña isla, un edificio de ladrillos, informe, casi desprovisto de ventanas, que dominaba una torre abierta en la cual una campana negra balancéabase en el cielo bermellón. Hubiérase dicho también que al ruido de los remos se mezclaban gritos de auxilio, lejanos. apagados.

-Esta-dijo Byron-es la casa de los locos. Todas las fardes, atravesando a esta hora, oigo la campana llamar a los locos a la oración.

- ¿Sin duda para agradecer al Creador sus bondades?

- Siempre el mismo. Shelley!-dijo Byron, rudamente,-iInfiel y blasfemadorl IY no sabe nadarl Cuidado con la providencia... Pero ¿no hablaba de vencer los instintos? ¿No le parece este espectáculo la imagen de nuestra vida? La conciencia es una campana que nos llama a la virtud... Como esos locos, obedecemos sin saber por qué. Luego el sol se pone, la campana se detiene, y es la muerte.

Miró a Venecia que, en la luz del crepúsculo, se había puesto gris rosada. -Nosotros, los Byron-murmuró-morimos todos jôvenes. Tanto por el lado de nuestro padre como de nuestra madre... No importa: quiero de todas maneras gozar de mi juventud.

\section{XXII}

Al otro dia Shelley, que había llegado a casa de Byron inquicto. se sorprendió agradablemente al hallarlo muy razonable. Ofrecia ceder a Shelley y Clara. por dos meses, una villa que poseía cerca de Venecia, sobre el Este. y autorizar a Allegra para residir un tiempo alli. El clima era sano: los niños estarian mejor que en eualquier parte. Shelley aceptó en el aclo y escribió a Mary:

He resuello lo que se debe hacer sin consultarte y quiero que vengas, mi bien amada, a reñirme si procedi mal, a darme un beso si he obrado bien... Mrs. Hoppner es bella, buena, tan angelicalmente dulce que si fuera al mismo tiempo sabia y hábil se convertiria complefamente en una Mary: pero no tiene tu perfección....

El viaje de Mary fué penoso: en Florencia los pasaportes la reluvieron bastante tiempo; la pequeña Clara, que echaba los dientes, sufrió mucho del calor y las fatigas y llegó a Este enferma.

Durante quince días estuvo mal. El médico de Este parecia completamente estúpido y Shelley y Mary resolvieron irse a Venecia a consultar otro. En Fusina la aduana austriaca quiso impedirles el paso de la laguna: Shelley atropelló por todo con violencia inaudita y se precipitó en la góndola. La pequeña tenía extraños movimientos convulsivos de la boca y de los ojos. Durante el trayecto pareció inconsciente. En el hotel los sintomas empeoraron. Un médico dijo que ya no quedaba esperanza. Y una hora después Mary se encontraba en 
una pieza desconocida, con su niño muerfo en los brazos. Mrs. Hoppner llegó y se la llevó a su casa. Al día siguiente por la mañana Shelley condujo el pequeño cadáver al Lido y Mary se esforzó por sacudir su tristeza.

Uno de los principios de Godwin consistía en que sólo las naturalezas débiles se abandonan al dolor, el cual dura poco si no nos complacemos en él por una cruel vanidad de sufrir. Su hija compartia estas ideas. Al dia subsiguiente del entierro, escribía en su diario:

- Leclura del cuarto canto de Childe-Harold. Llueve. Vimos el palacio de los Dux, el Duente de los Suspiros. etc. A la Academia. con Mrs. Hoppner: algunas bellas pinturas. Visita a Lord Byron, que estaba con la Fornarinas.

La Fornarina era la nueva querida de Byron. muchacha de aspecto plebeyo y salvaje.

-Veréis qué hermosa es-había dicho Byron a Shelley-Grandes ojos negros y un cuerpo de Juno. cabellos que brillan al claro de la luna, una de esas mujeres que, por amor, irian hasta el Infierno. Me gustan esta clase de animales y. ciertamen'e, habria preferido Medea a todas las mujeres del mundo.

Era en efecto un extraño $e$ indomable animal aquella muchacha, tan feroz. inspiraba terror a los sirvientes y hasta al gondolero gigante del poeta. Celosa. insoportable. falsa como un demonio y perfectamente ridicula desde que había querido reemplazar su bello chal veneciano por trajes elegantes y sombreros con plumas que Byron arrojaba implacablemente al fuego a medida que ella los compraba. Pero èl le toleraba sus locuras porque lo entretenía. Le gustaban su vivacidad, su acento veneciano, su violencia. Esta alma primitiva y cercana a las bestias reposábalo, decía, mejor que todo del trabajo intelectual. Gracias a ella su poema avanzaba alegremente. con un movimiento soberbio, con algo de la natural y ondulante furia del océano y de la mujer enamorada.

A los Shelleys, que eran la civilización misma, ese admirable bruto les desagradó. Se cruzaron miradas de tristeza. Durante los pocos días que vivieron aún en Venecia. Shelley vió más de cerca la existencia de Byron y la juzgó con severidad. El poeta asociaba a sus orgias a las mujeres que los gondoleros recogian en las calles. Después, descontento de sí mismo. decretaba que el hombre es despreciable. Su cinismo no pareció a Shelley sino una elegante máscara de la bestialidad.

Dor fin Mary y Percy regresaron a Este, tristes de no volver con su hijita. La casa era alegre. En el jardín, un parrón conducia a un pabelloncito delícioso que fué el retiro predilecto del poeta. Desde alli descubriase en el primer plano el castillo de Este: luego, como un mar verde. la planicie sin olas de la Lombardia, donde las bellisimas casas de campo emergian semejantes a islotes en el aire vaporoso: la solitaria Padua, y Venecia cuyas cúpulas y campanarios franjeados de oro brillaban en un cielo de záfiro. 
Shelley trabajaba. Habia comenzado un Prometeo y un drama lirico sobre el Libro de Job; pero ni aun en el trabajo encontraba la calma. la libertad de que tanto había gustado en Marlow. Pareciale que el dolor habia tomado el timón de la barca rrágil donde iban, bajo un cielo extranjero, el grupito de los jóvenes desterrados de Inglaterra.

\section{XXIII}

Después de mes y medio fué preciso devolver a Byron su villa y su hija. La lluvia invernal inspiró a Shelley el deseo de emigrar hacia el sur. Para sentirse feliz necesitaba el calor de la amistad: pero los climas y las ciudades desconocidos tentaban su melancolia.

El camino de Roma serpenteaba entre viñas rojizas. A cada paso encontraban parejas de bueyes blancos, de una belleza virgiliana. Atravesaron Ferrara. luego Bolonia, donde vieron tantas iglesias, estatuas y cuadros que la cabeza se les convertia en álbum de estampas célebres. Por Rimini. Spoleto y Terni. ciudades románticas, llegaron a la campiña romana, soledad perfecta, encantadora y sublime. Cuando entraron en la ciudad, un cuervo enorme planeaba por los aires.

La majestuosa tristeza de las ruinas eternas los impresionó. Shelley admiró el cementerio inglés. cerca de la tumba de Cestius, el más bello y el más solemne que hubiera visto jamás. El viento hacia cantar las hojas sobre los sepulcros. Alli hubiera querido reposar.

Después de un viaje de tres semanas, llegaron a Nápoles y arrendaron una casa desde donde se divisaba la bahia azul. siempre igual y siempre diversa. Noche y dia miraban humear ligeramente el Vesubio y reflejarse sus llamas y sus sombras en el agua del mar. El clima era el de una primavera inglesa, aunque talvez faltara ese crescendo, continuo de dulzura que da tanto encanto a los paises templados. Fueron a Pompeya, a Salermo, a Poestium, bellas visiones demasiado rápidas que les dejaban en el alma imágenes blancas y confusas, como de un suerio medio olvidado. A pesar de tanta belleza, no se sentian dichosos.

No conocian a nadie y el perpetuo aislamiento de su pequerio grupo se les hacía penoso. Bajo ese bello sol, pensaban en Richmond, en Marlow, en Londres. ¿Qué eran aquellas montañas y ese cielo azul sin un amigo? Los placeres de la sociedad son el alfa y el omega de la existencia y los paisajes presentes. tan reales y tan hermosos, desvanecianse al recordar la decoración de los sitios familiares, mediocres talvez, pero encantadores por el recuerdo.

En las calles. miraban con envidia a los pobres decirse buenos dias. Shelley tan lleno de ternura hacia los hombres, asombrábase de sentirse solo en medio de ellos. Mary. sobre todo, sufria de verse en todas partes como sla extranjera. De nuevo estaba al comienzo de un embarazo. Clara se le hacia insoportable. El sirviente ilaliano sedujo a la niñera suiza y. obligado a casarse, partió lleno de maldiciones y amenazas de venganza. Cansados. descontentos de Nápoles, regresaron a Roma. Una perpetua necesidad de cambiar los agitaba, como 
al enfermo que busca en el lecho un sitio fresco. llevando consigo la fiebre. El calor de la primavera romana pareció fafigar al pequeño William. El médico les aconsejó llevárselo rápidamente más al norte. Iban a partir, cuando. bruscamente, se declaró una disenteria. Durante sesenta horas no dejó Shelley la manecita de su hijo. Lo quería cada dia más. Era un niño inteligente, afectuoso y sensible. Tenia sedosos cabellos rubios, la tez transparente, ojos azules, animados y serios. Cuando estaba durmiendo, las mujeres italianas iban en puntillas a mostrárselo unas a otras. Agonizó tres días.

Lo enterraron en el cementerio inglès que su padre, al llegar a Roma. habia encontrado encantador por su silenciosa soledad. El viento cantaba aun entre las hojas. Cerca de una tumba antigua, en medio de las flores y de las yerbas soleadas. Shelley vió desaparecer el ataúd de su niño.

Fanny... Harriet... la pequeña Clara... William... Le pareció que una atmósfera pestilencial lo circundaba, infestando a los seres que le eran queridos.

La joven pareja. tan rudamente azofada por el destino, habia soportado hasta entonces con valor sus pruebas: pero esta vez Mary abandonó la lucha. Shelley se la llevó al campo, a una encantadora villa. Todo le era indiferente. Pensaba en unos pasitos que señalaban la arena de la playa napolitana, en esas expresiones ingenuas que pintan con tanta viveza el amor. el asombro. el gozo. Inmóvil los ojos fijos y como entorpecidos, no salia de su silencio sino para preguntar por la tumba romana; quería para su niño una estela de mármol blanco y flores.

Informado de su tristeza. Godwin se la reprochó con filosofia. Shelley mismo se quejaba suavemente: ‘Amiga mia cadónde has partido? Me has dejado solo en este mundo árido. Tu forma está ahi, encantadora, pero tu te has ido por el camino solitario que conduce a los sombríos extremos del dolor....

El tenia retiros aéreos y cuando en ellos se refugiaba desaparecian el mundo y la existencia no era sino un absurdo ensueño. Allá terminaba su Prometeo, nueva versión de su tema único: la lucha del Espíritu contra la Materia, del hombre libre contra el mundo. Júpiter representaba el papel de Lord Castlereagh: el Titán encadenado era otro Shelley, víctima llena de esperanza. confiada en el triunfo del bien. Bellos cielos sin nubes, forbellinos del viento tibio del Oeste, todo serviale para cantar desesperadamente su optimismo que ningún golpe abatia:

- Vientol Haz de mí tu lira como este bosque... ¿Qué importa si mis hojas también caen? Sé, para mis labios y para la tierra adormecida una trompeta de profecias $1 \mathrm{Ohl}$ viento. si el invierno viene ¿puede estar lejos la primavera?,

Cuando llegó el alumbramiento de Mary, se encaminaron a Florencia a fin de estar cerca de un buen médico. El mejor fué florencia misma, donde la soledad carece de amargura. En Florencia se vive con el Danle, se oye a Savonarola, se ve pasar a Giotto. Brunelleschi y Donatello rivalizan aun, amistosa- 
mente. en las iglesias y las estatuas viven con más familiaridad que en ofras partes. En la plaza, David vence al Neptuno imbécil y al torpe Héreules de Bandinelli. Se sufre menos de no conocer a los niños que pasan, mirando los de Della Robbia.

Gustábale a Shelley contemplar la ciudad desde las alturas de San Miniato. Los techos rosados dibujaban sus formas precisas: el Arno, henchido de lluvia, dejaba rodar sus aguas amarillas entre las viejas casas, que parecia una muchedumbre humana reunida en las riberas y los puentes: a los lejos, el valle descubría un horizonte de colinas azules.

En esa atmósfera cargada de efluvios espirituales. Mary se reanimó algo. Hablaba con algunas personas. El nacimiento del niño fué rápido y feliz. Cuando la madre se vió con una guagua otra vez en los brazos, sonrió por primera vez desde la muerte de William.

Lo llamaron Percy Florence.

\section{XXIV}

Todo en la vida llega por series. Un amigo trae ofro amigo. Mary y Percy. que habian sufrido tanto con la soledad, encontráronse de pronto, sin buscarlo, convertidos en el centro de un grupo muy animado y muy agradable.

La casualidad hizo el milagro. Primero Shelley volvió a sufrir su dolor al costado. El viento de los Apeninos, tan rudo en Florencia durante el invierno, se le hizo penoso y los médicos le aconsejaron irse a Pisa. que está màs abrigada.

Allá se le reunió Tom Medwin, uno de sus primos. antiguo oficial del Ejército, aficionado a las arles y que buscó la compañía del único literato de la familia. Era bastante aburridor, pero buen hombre, y relacionó a los Shelley con una pareja encantadora. los Williams.

Edgard Williams era. como Medwin, antiguo oficial de dragones. Habiase retirado por motivos de salud. según decia. Era un muchacho franco sencillo. sin pretenciones y que se interesaba por todo. Agradó mucho a los Shelley y su mujer les pareció deliciosa. muy linda, de modales refinados, excelente música. En el acto se estableció una profunda simpatia entre ambos esposos y los Shelley conocieron por fin esa dulce existencia de visitas espontáneas. elogios delicados y perfecta confianza que forma el encanto de las verdaderas amistades.

En cuanto un grupo existe. los que se sienten aislados se le agregan. Así se les unió un irlendés, el conde Taalfe, un griego. el principe Mavrocordato, y un extraordinario abate italiano, diabólico y penetrante, tipo de inquisidor de Venecia, el reverendo profesor Dacciani. Ilamado el Diablo de Pisa. maestro sin cátedra, gran conocedor en cuadros, anticuario. perito y comisionista universal. Era el hombre que siempre encuentra un epallazzo, que arrendar, cobra al arrendador $y$ al arrendatario, recomienda a un profesor de italiano y comparte con él el precio de las lecciones, mientras desliza misteriosamente al oido 
del viajero inglés el nombre de una Marquesa deseosa de vender un Andrea del Sarto.

Intimo de la casa en cuanto puso el pie en ella. Pacciani llamaba familiarmente a Mary y a su amiga Jane le belle inglese, y las entretenía contándoles las interioridades de los grandes señores de Pisa, cuyo amigo era

Uno de esos relatos emocionó vivamente a Shelley. El conde Viviani, el hombre más importante de la ciudad, acababa de casarse en segundas nupcias con una mujer mucho más joven que èl: había tenido de su primera esposa dos encanladoras hijas y la nueva condesa, celosa de su hermosura, había conseguido encerrarlas en dos conventos hasta que alguien consintiera en casarse con ellas sin dote. El prolesor, que había conocido a las contessinas, desde la infancia, hablaba con entusiasmo de su belleza y su inteligencia. La mayor, sobre todo. Emilia, era una especie de genio.

- Poverinal _decía Pacciani._Está como un pájaro en la jaula, viendo pasar sin objeto sus años juveniles. ella que está hecha para el amor. Ayer regaba algunas flores en su celda.-Si, les decia. Uds, nacieron para vegetar; pero nosotros, séres pensantes, estamos hechos para obrar y no para marchitarnos en el mismo sitio... Este convento de Santa Ana me parece un sitio horrible: las pensionistas tiritan de frio y no tienen para calentarse sino algunas cenizas en un tiesto de greda. Ud. se compadecerá de ellas.

Este caso despertó en Shelley todos sus sentimientos de caballero errante dormidos en la paz de la vida conyugal. Hizo mil preguntas, mostró tanta indignación contra el viejo conde, tanto interés por la bella víctima, que Pacciani, que no podia resistir el delicioso placer de entrometerse, suprema sensualidad de los viejos, le propuso llevarlo al convento de Santa Ana.

Era en efecto una casa miserable; los visilantes atravesaron un portal ruinoso: el abate fué a buscar a Emilia y luego Mefistófeles volvió con Margarita. No habia exagerado la belleza de la joven: llevaba los cabellos negros anudados simplemente como los de una musa griega; su perfil sin defectos parecía obra de un admirable escultor: la palidez del rostro hacia resaltar el brillo de los ojos. que poseían esa expresión medio adormecida y profundamente voluptuosa en que algunas italianas superan a las orientales.

Apenas entró en el locutorio. Shelley sintió que la amaba. Pero su amor no era deseo carnal, sino necesidad de sacrificarse y de admirar. Conservaba siempre en el fondo del alma la imagen de una perfecta belleza fisica unida a la belleza moral, el mito de una mujer encantadora y oprimida para convertirse en su caballero. Esa Andrómeda que yacía en el fondo de sus sentimientos amorosos le hizo raptarse a Harriet para sustraerla a su padre, amara a Mary porque era desdichada, mezcla de proporciones para él mismo desconocidas de sensualidad y compasión, sentimiento turbio en su origen, pero que él había sabido purificar y que exaltaba hasta el máximum su potencia poética. 
Durante largo tiempo creyó encontrar en Mary esa amante mistica; pero la vida en común es latal a las Tantasias sentimentales. En la bella y misteriosa Emilia, la diosa podía encarnar, porque no sabía nada de ella. Encontraba por fin en ese convento extranjero la vision admirable y fugitiva que perseguía desde la adolescencia y que, cada vez que intentaba cogerla, desvaneciase para dejarlo ante una mujer de carne.

Al penetrar en el locutorio. Emilia dirigió a un pájaro que estaba en una jaula un discurso que Shelley encontró el más poético del mundo:

- Pobre pequeñol iTe mueres de languidez! ¡Cuánto te compadezco! ıCómo debes sufrir oyendo las bandadas de tus hermanos que te llaman y parten para paises desconocidos! Como yo, aqui terminarás tu miserable destino... Oh! si pudiera libertarte!

Improvisaba así, a la italiana. especies de poemas hablados que no carecian de fuerza. Shelley la encontró genial. Le pidió permiso para volver a verla. llevarle su mujer y su cuñada. Ella consintió.

Refiriendo a Mary esta visita, no hizo misterio de sus sentimientos. Ambos leian mucho a Platón y Mary no ignoraba que ese amor era sólo la contemplación de la belleza pura. Hubiera preferido, sin embargo, que semejante contemplación tomara por objeto. alguna estatua o que, como Dante. Shelley no hubiera hablado nunca a su Beatriz. Sin embargo, lo acompañó al convento.

Reconoció que Emilia era muy bella, muy sestatua griega., y de una elocuencia sorprendente; pero, en el fondo de su corazón, prefería la púdica reserva de los ingleses a ese genio italiano demasiado expansivo. Encontró que Emilia hablaba fuerte, que sus gestos carecian de gracia y que resultaba más agradable cuando permanecia en silencio. Se guardó de mostrar fales sentimientos.

Clara, más sensible, se sintió conquistada como Shelley. Mientras Mary le llevaba a la cautiva libros, una cadena de oro y otros regalos. Clara, que era pobre, ofrecía lecciones de inglés. Emilia acepló con entusiasmo. Una incesante correspondencia se cruzó entre el convento y Pisa; no eran sino: Querida hermana... Mary adorada... Sensible Percy... Caro fratello... y aun, en sentido místico se entiende, adorato sposo. A veces la equerida hermana Mary, parecía algo fría. .Pero su marido me dice que esta frialdad aparente no es sino la ceniza que cubre un corazón afectuoso.

La verdad es que la querida hermana Mary sentiase enervada. Ya Shelley estaba construyendo en torno a Emilia uno de esos mundos imaginarios a los que gustaba evadirse: componia para ella un gran poema de amor tan misterioso como la Vita Nuova del Dante o los sonetos de Shakespeare. Proclamaba en él su doctrina:

-Nunca he pertenecido a la secta de los que sostienen que sólo se debe tener una amante y leer un libro y que el resto debe condenarse al olvido...

Trazaba un retrato de Emilia que era un himno a su belleza. Nlamábale esposa. hermana, ángel...

Aunque Mary se repetia que todas esas cosas se dirigian a la divina esencia 
de Emilia, no a una linda muchacha de cabellos negros. le era penoso ver trabajar a Shelley con tanta exaltación. Por suerte, el trabajo lo absorbia al punto de no dejarle tiempo para visitar a su heroina. Y mientras el amante platónico acumulaba imágenes vaporosas, el padre de la joven le enviaba proposiciones cínicas, ofreciéndole un marido viejo y rico, un tal Biondi, dueño de un castillo lejano. $\mathrm{Y}$ antes de terminar el poema, recibió Shelley la noticia del matrimonio de Emilia.

\section{XXV}

Durante los primeros meses después de su salida de Venecia, Clara recibia regularmente noticias de Allegra por los Hoppner. La pequeña sufría con la baja temperatura. Se habia puesto seria como una viejecita y Mrs. Hoppner opinaba que la sacaran de Venecia. Pero resultaba imposible entenderse con el padre, cada vez más enfangado en las orgias.

Pasó algún tiempo sin noticias. Llena de ansiedad, Clara escribió carta tras carta a la mujer del Cónsul, hasta que supo los cambios que se habian producido en la vida de Byron. Empezaron por una enfermedad bastante grave que lo retuvo en cama. Hoppner. al hacerle compañia, le refirió que sus amores, lejos de escandalizar a la gente, alimentaban las econverzazioni. y decian que las mujeres se burlaban de él y le robaban. Don Juan se habia enfurecido e inmediatamente despachó a todas las sacerdotisas del palacio Moceniso.

Durante la convalecencia, se le vió en los salones de Venecia, largo tiempo abandonados por él. Alli encontró la mujer más linda de Italia, a la condesita Guiccioli, encantadora rubia de diecisiete años que acababa de casarse con un respetable caballero. El peregrino la encontró admirable, sobre todo muy bien formada de cuerpo. El primer día, le entregó un billetito. Era una cita. Ella acudió. El que decía amarla era un gran poeta, noble, rico, hermoso. Cedió sin combatir.

Dias más tarde el conde Guiccioli partió con su mujer a Ravena y Teresa rogó a Byron que los siguiera. Olvidaba que la mujer puede manejar al hombre antes... pero después... La idea del amor romántico y constante repugnaba a Byron. No se movió y se mostró muy soberbio de su resistencia.

De Ravena ella le mandó decir que estaba enferma y lo que el amor no pudo lo hizo la compasión. Don Juan se puso en camino, deteniéndose en Ferrara y otras ciudades para admirar las bellezas históricas. Aún cuando afectara indiferencia y hastio, iba de bastante buena voluntad. Las mujeres inteligentes como Clara o Lady Byron lo fatigaban pronlo: despreciabe demasiado al otro sexo para pedirle compañia intelectual. Las bellas panaderas y las vendedoras de Venecia eran de una especie demasiado diversa de la suya. Pero la condesita Guiccioli juntaba a una reposante y afectuosa tonteria las gracias de la mujer bien educada y logró cautivar sin mucho trabajo al eterno fugitivo. Don Juan se convirtió para ella en un enfermero fiel y hasta sentimental. Si la perdiera-escribia-perdería a un sér que ha corrido grandes peligros por mi y a 
quien tengo toda clase de motivos para amar. No sé lo que haria srealmentes si muriera; pero sé que deberia matarme y espero que lo haré....

Cuando su conquistadora conquista abandonó Ravena, la siguió a Bolonia. Se convirtió en el clásico Sigisbeo....

Clara supo toda esta historia y que Byron residia en Bolonia con Allegra. La idea de que su hija habitaba en casa de la nueva querida del poeta. mujer que no tenía por qué amarla y que acaso la odiaba, le produjo verdadero espanto. Escribió una carta apasionada para recuperarla. Byron repuso: eRepruebo lanto la educación que la familia Shelley da a los niños que creería mandar mi hija al hospital si se la enviara. $O$ irá a Inglaterra o la pondré en un con. vento. No me dejará para morir de una indigestión de fruta verde o para crecer con la idea de que Dios no existe....

Al recibir esta carta. Clara anotó amargamente en su Diario: Carta de Lord Byron sobre la fruta verde y Dios.: pero lloró mucho. Le parecia horroroso el proyecto de internar a Allegra en un convento de monjas italianas, desprovistas de toda noción de higiene y de amor a la infancia. Dirigió a Byron cartas desesperadas, violentas, casi insolentes. Don Juan se quejó a Shelley. quien le aconsejó no hacer caso. Tenía bastante con las complicaciones de su propio hogar. El incomparable Godwin, su filósolo y suegro, lo abrumaba pidiéndole dinero y hubo de responderle:

- Mary no tiene dinero: si lo tuviera, la desdichada. se lo daría todo a Ud. Un padre semejante, quiero decir, un genio como Ud. debe tener otros temas que tratar con su hija $\mathrm{e}$ interceptaré sus cartas que traten de la cuestión financiera. Ariel se ponia duro.

Mary inquiela por su padre. Clara por su esposo, se exasperaban la une a la otra y la admiración común hacia el único hombre de la casa constituía un obstáculo para su mutua inteligencia. Mary hacia lo posible por que Clara se sintiera de más: ésta acabó por resignarse y aceptó un puesto de institutriz en Florencia.

\section{XXVI}

El 16 de Septiembre de 1820. Hoppner escribió a Lord Byron una larga carta refiriéndole las noticias del hogar de los Shelley que le habia comunicado Elisa. la sirviente de confianza. Clara habría tenido un hijo de Ariel. en Nápoles, en gran secreto, y las disensiones serian continuas entre los esposos y la cuñada, al punto de injuriarse groseramente por los más fútiles motivos. Byron creyó toda la historia y. aunque había prometido el secreto a Hoppner. la primera vez que vió a Shelley se la refirió y le mostró la carta del Cónsul. Percy transmitió inmedialamente el recado a su esposa, rogándole que escribiera a 
Hoppner para deshacer la atroz calumnia. Mrs. Shelley lo hizo asi, con lágrimas y protestas del alma.

No obluvo respuesta.

Entre tanto. Allegra residía en un convento de Ravena, aprendia una cantidad prodigiosa de oraciones, soñaba con el paraiso y recitaba letanias de santos. Esta educación le gustaba a su padre.

Byron vivia con esplendidez. La Guiccioli lo había regenerado y tenia de nuevo el rostro fresco y radiante de juventud. Su mismo sirviente. Fletcher. engordaba. como engorda. la sombra. En la escalera de mármol ocho enormes perros, tres monos, cinco gatos, un águila, un papagayo y un halcón se armaban querellas. Las pesebreras encerraban diez caballos.

Cuando se dispuso a movilizarse con todo este equipaje, hubo en Pisa la agradable agitación que causan los soberanos en viaje. Mary le arrendó la más bella casa de la ciudad, el palacio Lafranchi y la puso en estado de recibir a su ilustre huésped. Luego llegó la Guiccioli, con su padre, el conde Gamba, y los Shelley los recibieron. Esa italiana linda y sentimental les encantó.

Por fin, apareció don Juan en persona. Toda Disa habia salido a las ventanas para ver pasar el demonio inglés con su cortejo. El desfile merecia verse: cinco carruajes, siete criados, nueve caballos, perros, monos, pavos reales e ibis. Los Shelley temian por la impresión que causaria su palacio: pero le gustó. Byron declaró muy hermosa esa residencia medio-eval. Era del siglo XVI; pero el noble Lord mezclaba siempre los estilo. Sobre todo las bodegas húmedas y sombrias le parecieron muy románticas. Las bautizó subterráneos y calabozos, hizo descender cojines y se instaló en ellas para dormir.

Desde su llegada, Byron lué el centro mundano del pequeño círculo de Pisa, Shelley siguió siendo el centro moral. Iban donde Byron por curiosidad. por admiración. Donde Shelley. por simpatía. Shelley se levantaba temprano, leía hasta las doce, Goethe. Spinoza, Calderón: después se iba a los bosques y en la soledad de los pinos trabajaba hasta la noche. Byron se levantaba a medio dia, almorzaba sobriamente, paseaba a caballo y tiraba al blanco. De noche visitaba a su querida, regresaba a las once, se ponía a trabajar a veces hasta las dos y tres de la mañana.

La colonia inglesa lo buscaba. Los más puritanos no pudieron resistir mucho a un lord auténtico que les llevaba a tierra extraña un tan delicioso compendio de todas las vanidades británicas. Su deseo de escandalizar ¿no demostraba por lo demás el respeto más ortodojo? La indiferencia es una ofensa, el desafio un homenaje. ¿No se veía que no podia vivir sin salones que visitar. mujeres que seducir. comidas que ofrecer? Todo el mundo lué muy indulgente con êl, menos cuando quiso imponer a Shelley. Lo resistieron con obstinación. Shelley se aburria en sociedad y no lo disimulaba. Su moral, se decía que preTería el espiritu a la letra, que creía más en la redención que en el pecado original. La fe en la perfectibilidad del hombre es la más imperdonable: obliga a tener voluntad. La frivolidad la ollatea desde lejos y la persigue. Las mujeres realmente distinguidas trataron a Shelley como sospechoso. 
El se burlaba: pero Mary quería que la invitaran. Una Mrs. Beckett ofrecía bailes epor estar afligida-decía Byron-por una carga de siete hijas, todas en la edad en que esos animales deben danzar para ganarse la subsistencias. Era una idea fija de Mary asistir a una fiesta de Mrs. Beckett. Todo el mundo asistes - decia. elTodo el mundols y Shelley miraba al cielo. „Todo el mundol ¿Cuál es ese monstruo mitológico? ¿Lo has visto?. Para complacer a todo el mundo. asistió a un servicio del pastor anglicano: pero predicó en contra los ateos mirándola con tal insistencia, que a pesar de todo su ardor conformista no creyó digno volver a la iglesia.

Para consolarse de estas pequeñeces. Shelley se refugiaba en casa de los Williams. Amaba a Jane, como en otro tiempo a Mary, a Harriet...; pero ya sin esperanza y casi sin deseo. Ella se prestaba a este juego romántico y acariciāndole la frente lo libraba de los malos pensamientos.

Los Williams hablaron a Shelley de un amigo. Trelawny, que deseaba conocerlo y poco después fucron a hacerle visita en su compañia. Timido, ruborizado. Shelley entró en el salón de su casa y estrechó calurosamente las manos de Trelawny, que lo miraba con sorpresa. no pudiendo creer que esa cara femenina fuera la del hombre aborrecido como un monstruo en Inglaterra y privado por el Lord Canciller de sus derechos paternales.

- ¿Qué libro lee?-le preguntó Jane.

- El Mágico Prodigioso de Calderón, repuso.

-Oh! léanos...

Encantado. Shelley empezó a traducir en voz alta con una perfección de forma y una seguridad de expresión tales, que Trelawny quedó aun más sorprendido.

Terminada la lectura, levantó la vista y no divisando al lector, preguntó:

- ¿Pero dónde está?

- ¿Quién, Shelley? Ahl es como los espíritus: se evapora.

Al otro dia, visitaron a Byron. Vestibulo de mármol, escalera gigantesca, lacayos, perros. Tralawny. como todo el mundo, encontró que Byron tenía toda la apariencia del genio; pero su conversación le pareció extrañamente banal, Parecía incómodo, representando un papel antiguo: contaba historias de borrachos, de boxeadores, de actores $e$ insistía mucho en que habia cruzado a nado el Helesponto.

A las tres salieron a caballo y se entretuvieron en tirar al blanco. Trelawny vió con agrado que Shelley, a pesar de su aspecto femenino, tiraba como un hombre. Al volver, hablaron de literatura, de rimas ricas y Trelawny citó dos estrofas de Don Juan, conquistándose el aprecio de Byron que se puso a trotar a su lado y le dijo:

- Vamos, confiese Ud. que me creia un Timón de Alenas y está sorprendido de encontrarme hombre de mundo. dispuesto a reirme de todo... 
Trelawny regresó en compañia de Shelley y Mary.

- Qué distinto es Byron-dijo-de lo que se esperarial No tiene nada de misterioso, habla libremente, dice cosas que más valdría callar. Prece celoso e impulsivo como una mujer y talvez más peligroso.

- Mary!-dijo Shelley-Trelawny ya ha desenmascarado a Byron. IQué tontos hemos sidol ICuánto tiempo nos ha costadol muertos.

-Es que-repuso Mary-Trelawny vive con los vivos y nosotros con los

\section{XXVII}

Marino. aventurero, hombre de acción. Trelawny llegó a Pisa dispuesto a admirar a los grandes hombres y luego fué objeto de viva admiración de parte de ellos. Cierto que a sus espaldas Byron decia:

- Si le enseñáramos a lavarse las manos y no mentir hariamos de él un egenfleman.

Pero lo trataba con gran respeto. Como todos los artistas. Byron y Shelley sólo creaban bellas formas para consolarse de no poder vivir. Y el hombre de acción se les aparecia como un fenómeno extraño, envidiable.

Shelley lo consultaba sobre términos náuticos y dibujaba con él. sobre las arenas de las riberas del Arno, quillas, velas y cartas marinas.

-Erré mi destino-decia-Debí ser marinero.

-No puede ser marino un hombre que no luma ni blasfema-respondia Trelawny.

Byron, corsario de imaginación, habria querido que el corsario verdadero le enseñara las costumbres de la profesión y en su presencia se esforzaba por demostrarse audaz y cinico. Trelawny, que advirtió su influencia, se propuso utilizarla en favor de Shelley.

- ¿Por qué no habla Ud. en sus obras de Shelley-dijole un día-como to ha hecho con otros de menos talento?

Byron recibió mal la insinuación:

- Todos los oficios tienen su secrefo-repuso-y si elogiamos a un autor popular nos paga en la misma moneda. IPero Shelleyl ¿Quién lo lee? Por lo demás. si renunciara a la metafisica no necesitaría ayuda de nadie.

- Pero ¿por qué sus amigos lo tratan mal? Ni siquiera lo saludan en su casa...

- Es que no es cristiano.

- ¿Y cllos?

-Pregünteselo.

- En cuanto a mi-dijo Trelawny-si encontrara al diablo en su casa de Ud. lo trataría como a uno de sus amigos.

El peregrino lo miró severamente para ver si la comparación era intencio- 
nada: luego acercando su caballo. murmuró a su oído con un aire de tenor y respeto perfectamente simulàdo:

-El Diablo es de estirpe real.

Con los Williams. Trelawny hablaba francamente:

- Se diria que Byron envidia a Shelley, a pesar de que su editor tiene que llamar policia cuando aparece un nuevo canto de Childe-Harold, mientras a Shelley no lo lee nadic; Byron tiene la fortuna, la nobleza, el amor y la gloria...

- Si-respondia Williams-pero Byron es el esclavo de sus amores y de cualquier mujer un poco resuelta. Shelley. es su cáscara de nuez, se atraviesa en la corriente de Arno y la corriente no se lo lleva. Tiene ideas firmes y doctrinas. Byron, no. Lo sabe y no le perdona a su amigo su firmeza. Vea con qué tono triunfal habla de las desdichas de Shelley...

-Byron-dice Jane-es un niño regalón. No ama a los hombres. Shelley los ama demasiado. Ninguno los conoce.

- Lo terrible-añadió Trelawny-es que Shelley carece del instinto de conservación en absoluto. El otro dia se lamentaba de no saber nadar, mientras yo me bañaba en el Arno.-Ensaye-le dije-poniéndose de espaldas. Se desnudó. se tiró al agua, se puso de espaldas y se fué al fondo. No se movia. Si no lo saco, se ahoga.

Jane suspiró: no ignoraba que la idea del suicidio obsesionaba al poeta.

- Dero no parece desdichado.

- Porque se refugia en los sueños. En la realidad. sus libros sin lectores, su hogar imperfecto. su impotencia para influir... ahl la vida debe parecerle una pesadillal

- Cree en una existencia futura-decia Trelawny,-Los que lo creen ateo lo desconocen. Ya renegó de la filosofia francesa del siglo XVIII. Platón y Dante han vencido a Diderot. Dero no se retracta... Yo le preguntaba:- ¿Por qué se dice ateo? Lo perjudica tanto en sociedad... Y me ha contestado: Es un diablo de cartón para asustar a los imbéciles.

Asi discurria el coro unánime y talvez no veían que su adoración por Shelley provenia en gran parte del fracaso temporal de éste. Al hombre le gusta más admirar lo que compadece que lo que envidia. Encuentra en el espectáculo de un fracaso inmerecido agradables argumentos para explicarse su propia suerte. Y la mezcla de la admiración y la piedad constituye una de las más seguras recetas para producir el afecto. Los Williams y Trelawny habrian necesitado mucho más modestia para amar al brillante Byron como amaban al pobre Shelley.

Mientras los discípulos hablaban del maestro ausente. èl trabajaba en el bosque de pinos que rodea a Pisa. Alli, el viento del mar habia derribado un 
grande árbol sobre un estanque $\mathrm{y}$ en ese tronco suspenso sobre la ribera, como un päjaro salvaje, había formado Shelley su nido. Desde lejos se divisaba su antro. sembrado de hojas de papel esparcidas por el suelo con estrofas inconclusas

Cuando en su ensueño olvidaba la hora de comer y su propia existencia, Mary iba a buscarlo. Trelawny la acompañaba; se había constituido en el caballero de esa mujer abandonada y le hacia una corte de pirata que la divertía mucho. Fatigada, solía sentarse a la entrada del bosque y Trelawny partia a caza del poeta. Un dia lo encontró tan absorto en su visión lejana que no se atrevió a despertarlo sin haber llamado antes su atención haciendo sonar las hojas secas y quebrando ramas de pinos. Recogió un Esquilo, un Shakespeare. luego un papel garabateado: .A Jane, con una guitarra.... Pero sólo pudo descifrar dos versos:

Ariel to miranda. Take this salave of music...

-Ehl ¿Esta es su sala de trabajo?

Si. Y los árboles mis libros. Al componer, necesito mi atención y las puertas, las campanillas, los pasos me disuelven mis visiones.

-Aqui están el rio. los pájaros...

- El río corre como el tiempo y los sones de la naturaleza apaciguan. Sólo el animal humano es disonante y me incomoda. Ohl qué difícil es concebir por qué estamos aqui. perpetuos tormentos los unos para los otros!

Trelawny le recordó que su mujer lo esperaba. Se levantó de un salto. suspirando:

- Pobre Maryl No puede soportar la soledad ni yo la compañia... Una viva uncida a un muerto.

Y partió con su paso rápido, deslizante, de espiritu de los bosques.

\section{XXVIII}

Byron había prometido llevarse a Allegra a Disa: pero no lo hizo y Clara que llegó de Florencia a verla, tuvo terribles presentimientos al saber que su hija estaba en el convento de las monjas de Bagna-Cavallo, antihigiénicas y duras. Se lo escribió a Byron, le prometió no verlo nunca más, ni a él ni a la niña, si se la llevaba a algún buen colegio de Inglaterra; pero don Juan se mostró indeferente e inflexible. La desesperación de Clara llegó a tal punto, que Shelley se la llevó a la costa, con los Williarns.

Alla mandaron construir un yatch, que bautizaron Don Juan, en honor de Byron, el cual, por su parte, encargó otro mayor. que llamó Bolivar. Los dos se consideraban ya señores del Mediterráneo. Sus mujeres detestaban semejante diversión. 
Poco después. Shelley recibió carta de Byron. Allegra había muerto. Se declaró una epidemia y las monjas no tomaron ninguna precaución.

Temerosos de que Clara cometiera alguna violencia si estaba cerca del poeta, se la llevaron lejos para anunciarle la terrible noticia. Su dolor no tuvo limites. Escribió al padre una carta afroz. Byron repuso que haría grandes funerales. Resolvió enterrar a su hija en Inglaterra, en una iglesia de Harrow. con esta lápida:

\section{A LA MEMORIA DE ALLEGRA}

hija de Jorge Gordón Lord Byron, muerta

en Bagna-Cavallo. el 20 de Abril

de 1822. a los

cinco años y seis meses de

edad.

Iré a ella, pero ella no ven-

drá nunca a mi....

(Samuel, XIII-25).

El vicario de Harrow encontró inmoral admitir una hija ilegitima y resolvió sepultarla fuera de la iglesia, sin inscripción alguna.

Byron visitó después el Convento de Bagna-Cavallo y escribió una hermosa poesia sobre el tema de la muerte de su hija, a quien nunca fué a ver.

Shelley y sus amigos habitaban juntos Casa Magni, cerca del mar. Mary. de nuevo en cinla, sufria mucho y tenia pequeñas rencillas con Jane a propósito de los criados y de las cacerolas. Su esposo la compadecía sinceramente: pero no remediaba nada. Seguía tan ignorante como siempre de la realidad.

Todos los meses iba a Livourne a recoger sus rentas. Volvia con un saco lleno de monedas que vaciaba en el suelo. de un golpe. Luego, con las tenazas de la chimenea. Iormaba tres montones: uno para los gastos de la casa, otro para Mary. otro para él. Este último, a pesar de sus promesas, iba a parar casi integro a manos de Godwin, de Clara, de los Hunt, de cualquiera.

Un día Mary había invitado a comer a Casa Magni a dos personajes ingleses notables, descosos de conocer al poeta. A la hora de comida. Shelley no había aparecido y se sentaron a la mesa sin él. De pronto una de las señoras lanza un grito:

-Ohl bondad divinal

Mary, volviéndose, divisó a Shelley complefamente desnudo que atravesaba el comedor disimulándose detrás de la sirviente.

- Percy. es posiblel

Fatal imprudencia: sintiéndose acusado injustamente. Shelley abandonó su refugio y se acercó a la mesa para disculparse. Las señoras se lapaban el rostro con las manos. Sin embargo, estaba encantador, con los cabellos llenos de al- 
gas. el cuerpo frágil y húmedo. perfumado de sales marinas. Pero a Mary le horrorizaban esos incidentes.

Shelley y los Williams esperaban con impaciencia de niños el arribo del yatch. Después de la muerte de Allegra, escribieron a Génova para que le quitaran el nombre de Don Juan y le pusieran Ariel. Todo lo de Byron les causaba horror. Su sorpresa y su cólera no tuvieron limites cuando llegó el pequeño navio y leyeron en sus velas: -Don Juan?, en letras enormes. Byron, informado del cambio, ordenó que mantuvieran el sello diabólico en la barca platónica. Con agua tibia, jabón, brocha. Shelley y Williams trabajaron por lavar de infamia la tela. Fué inútil. Ensayaron ácidos. Nada. Consultados algunos especialistas. dijeron que seria necesario cortar el pedazo y recoserlo. Asi se hizo.

El capitán genovés que llevó la barca la encontraba buena, rápida, pero difícil de manejar con mal tiempo. Williams y Shelley, entusiastas incompetentes. habian impuesto un modelo regio cuya línea elegante les encantaba y se necesitaron dos toneladas de plomo para equilibrarlo. Aun asi era inseguro.

Los propietarios de Ariel querian tripularlo con un solo grumete. Williams había estado tres años en la Marina inglesa; Shelley. torpe, pero con buena voluntad, pretendía secundarlo. Se enredaba en los cordajes, leia a Sófocles teniendo la barra del timón, a cada instante resbalaba sobre cubierta, estaba a punto de caer al agua. Trelawny les aconsejó que contrataran un buen marinero. conocedor de la bahía. Williams se sintió muy ofendido. Era capitán y tenía a Shelley.

- Shelley! No hará nada mientras no se corte los cabellos, no tire los trágicos griegos por la borda y no meta los brazos hasta el codo en un tonel de alquitrán.

El Ariel, por exceso de calado, no podía acercarse a la playa. Construyeron una minúscula canoa de madera y tela de buque, ligera cáscara, juguete delicioso. Una tarde Shelley invitó a Jane a pasear en la navecilla con los niños.

- Con un poco de precaución habrá sitio para todos-dijo.

Ella se apelotonó al fondo. Los bordes bajaron casi a flor de agua. Un movimiento brusco y naufragaban. Pero pensó que sólo irian por la orilla. Encantado del paseo. Shelley lució su habilidad de remero alejándose de la ribera y luego estuvieron a la distancia. Allá el poeta cayó en profundo ensueño. Jane, aterrada. le dirigió suavemente algunas preguntas. No respondia. De pronto. levantó la cabezo, como iluminado y dijo:

- Vamos a resolver juntos el gran misterio.

Si Jane hubiera gritado, ella y sus hijos se perdian. Shelley habria hecho un movimiento brusco. Ligera, alegre, repuso:

-No. gracias; querría comer antes y acostar a los niños.

Como Shelley insistia, ella, sintiendo pasar el ángel de la muerte, agregó:

-Además Ud. no ha escrito las palabras del himno indio que me prometió. 
Este argumento convenció al marino y remó hacia la playa. En cuanto se vió cerca de la arena. Jane seltó con sus niños tan aprisa que la canoa se dió vuelta y quedaron debajo.

- Jane ¿estás loca?-dijole su marido.

-No, al contrario. Buena escapada! Ahl es un sepulero horrible... Nunca más pondré los pies en él. Resolver el gran misterio... El más grande de lodo es el mismo... Querria irme; vivo en contínuo terror.

Pero el rostro infantil del poeta parecía radiante e inocente. Nada perfurbaba su dicha en aquella tarde de otoño. Gustábale, por las noches, navegar en el Ariel al claro de la luna. Mary, sentada a sus pies, la cabeza entre sus rodillas, recordaba que diez años antes habian cruzado asi el canal de la Mancha. IQué de acontecimientos desde entonces! iY cuánto más sutil, y más traidora era la vida de lo que ellos habian imaginadol

Sentada a popa, Jane cantaba una serenata indú en su guitarra. Shelley miraba al cielo apacible de Junio, las franjas brillantes de las nubes bajo la luna. Su carne se disolvia en los perfumes tibio de la noche. Era un vapor extático. una voz deliciosa. Dejando la tierra por las formas fluidas y puras de sus sueños, se sostenía en los espacios gracias a la música divina. a los vapores trans. parentes, a los impalpables fantasmas. Sabia la existencia de otro universo, rudo e inflexible; pero en las altas regiones por donde bogaba sólo existia la dulzura ondulante. el canto liquido e invisible: el movimiento de las esferas luminosas, y nada, nada, ni celos de mujeres, ni querellas politicas, ni pequeñeces de dinero podian perturbar su increible dicha.

\section{EPILOGO}

Hacía tiempo que Shelley queria llamar a Italia a sus amigos Hunt. a quienes sus acreedores y sus enemigos politicos perseguian en Inglaterra. Les ofreció pagarles el viaje; pero como sus recursos no le permitian costearles la subsistencia-eran siele personas - consiguió con Lord Byron que fundaran un diario liberal y alojara a la tribu en el piso bajo de su palacio de Pisa.

A principios de Junio de 1822 llegaron a Livornia. En el puerto los esperaban Shelley y Williams en el Ariel y Trelawny en el Bolivar. Debian regresar inmediatamente; pero retardaron el viaje y en la mañana del 8. Shelley resolvió embarcarse con Williams y un grumete.

El capilán Roberts les pronosticó mal tiempo y a poco de haber zarpado estalló, efectivamente, la tempestad.

Al otro lado del gollo las mujeres esperaban inquietas. Llovia sin cesar. Y pasaron así el Lunes. el Martes, el Miércoles. Ese día el patrón de una barca les dijo que el Ariel habia partido tres dias antes. No le creyeron. En la tarde llegaron cartas, una de Hunt para Shelley: 
-Diganos cómo ha llegado, porque había tan mal tiempo el dia de su partida que no estamos tranquilos....

La carla se le cayó de las manos a Mary, Jane la recogió y dijo:

- Todo está perdido.

Cinco dias más tarde se encontró en la playa de Viareggio un cadáver horriblemente mutilado por los peces. Llevaba en los bolsillos un tomo de Sófocles y otro de Keats, todavía abierto. como si el lector, sorprendido por la tempestad. lo hubiera metido alli precipitadamente.

Mary quería que enterraran a Shelley en el cementerio de Roma: pero los reglamentos sanitarios no lo permitian y Trelawny sugirió la idea de quemar los cadáveres en la playa, al modo de los antiguos griegos. Byron fué llamado para presenciar la ceremonia lúnebre.

Desenterraron los cuerpos de su sepulero de arena y los arrojaron en una gran pira hecha de pinos. El calor hacia temblar el aire. Al cabo de tres horas. el corazón de Shelley, de un tamaño enorme, no se habia consumido aun: Trelawny. mediante unas tenazas, recuperó esa reliquia. El cráneo se abrió por si solo y dentro la masa encefálica hervía como en una caldera.

Byron no pudo soportar el espectáculo. Se quitó la ropa, echóse al agua y nadó desnudo hasta el Bolivar. anclado en la bahía. Trelawny recogió las cenizas y los huesos blanqueados y los depositó en una urna de encina forrada en terciopelo negro.

¿Cuál fué la suerte de los personajes de esta historia?

Sir Timothy Shelley vivió hasta los 90 años y fijó una pequeña pensión a Mary. a condición de no publicar las poesias de su esposo mientras viviera el baronet.

A su muerte, Percy Florence heredó la fortuna y el título.

La desdicha unió a las dos viudas, Mary y Jane. Vivieron juntas en Italia y en Londres. Los amigos de sus maridos eran tan fieles que Trelawny pidió la mano de Mary y Hogg la de Jane. Mary rehusó, alegando que encontraba demasiado hermoso el nombre de Mary Shelley. Jane aceptó: pero en el momento del matrimonio confesó que nunca había sido casada con Williams y tenía un marido, en alguna parte, en las Indias, lo cual no fué obstáculo para que ambos vivieran juntos. en perfecta armonía. sin mayor ceremonia.

Clara se quedó en el continente y fué institutriz en Rusia. A la muerte de sir Thimothy, heredó una importante suma que le habia legado Shelley y que le sacó de la miseria.

Mientras avanzaban en años, las tres mujeres tenian frecuentemente rencillas a propósito del muerto. Jane prefendia que durante los últimos meses, en Pisa y 
Casa Magni, Shelley no la habia amado sino a ella. Mary se fastidió y dejaron de visitarse.

Clara preparaba un libro para demostrar. con los ejemplos de Shelley y Byron. como era necesario para la felicidad tener sobre el amor ideas vulgares: pero se le trastornó un poco la cabeza y hubo de reposar mucho tiempo. Vivió en Florencia y se convirtió al catolicismo.

Hacia 1879. un joven que buscaba documentos sobre Byron y Shelley le hizo una entrevista. En cuanto pronunció aquellos dos nombres. vió aparecer entre las arrugas de la anciana señora una de esas sonrisas de muchacha, limidas y llenas de promesa que la habian hecho encantadora a los veinte años.

- Vamos-dijo-Ud. creerá. como lodos, que yo amé a Lord Byron.

Y como el la mirara sorprendido:

- Amigo-agregó- llegará un día en que Ud. conocerá mejor el corazón de las mujeres. Byron me deslumbró: pero nunca lo amé. Habria podido amarlo; pero no fué asi.

Hubo un largo silencio.

-Entonces. señora ¿Ud. no ha amado nunca?

La anciana enrojeció y bajó la vista.

- ¿Shelley?-murmuró él con voz imperceptible.

- iCon toda mi alma y lodo mi corazón!-dijo la señora, apasionadamente. sin levantar los ojos.

Luego, con encantadora coquelería, le dió una palmada en la mejilla. 